\title{
A LINGUISTIC ANALYSIS OF HEIKKI OJANSUU'S PHONOGRAPH RECORDINGS OF KRAASNA
}

\author{
Tobias Weber \\ Ludwig-Maximilians-Universität München, DE \\ weber.tobias@campus.lmu.de
}

\begin{abstract}
The South Estonian Kraasna subdialect was spoken until the first half of the 20th century by a now vanished community in Krasnogorodsk, Russia. All linguistic descriptions to date are based on textual sources, mostly manuscripts from Heikki Ojansuu's 1911/12 and 1914 fieldwork. Ojansuu's phonograph recordings were thought to be lost by previous researchers and remained unused. The rediscovery of these recordings allows for the first analysis of Kraasna based on spoken language data, closing gaps in the description and enabling further research. This description follows a theory-neutral and framework-free approach, while respecting traditions in Estonian linguistics and linking the results to research in Estonian dialectology. It provides key information on the Kraasna subdialect based on the corpus - phonology, morphology, syntax - despite being restricted to the phonograph recordings. Future research can expand on these points and build on the present description.
\end{abstract}

Keywords: linguistic enclaves, historical sociolinguistics, Estonian dialectology, documentary linguistics, phonograph recordings, South Estonian, Kraasna

DOI: https://doi.org/10.12697/jeful.2021.12.2.13

\section{Introduction}

The extinct variety historically spoken by the Kraasna community is traditionally seen as a South Estonian variety and is either grouped with the linguistically similar (Võro-)Seto subdialects (Kask 1956, Iva 2015, Pajusalu et al. 2020) or geographically with the other two South Estonian linguistic enclaves in Latvia (Pajusalu 2007, Mets et al. 2014). In either case, Kraasna is part of the extreme periphery and thus less relevant to (contemporary) developments and contact phenomena among Estonian dialects (cf. Pajusalu 1997), while providing important insights into historical developments and contact phenomena with other languages (e.g., Pajusalu \& Muižniece 1997, Krikmann \& Pajusalu 
2000, Pajusalu 2005). However, these descriptions are based on a relatively small corpus, as there were only two researchers who managed to gather texts and authentic speech from native speakers - Oskar Kallas in 1901 and Heikki Ojansuu in 1911/12 and 1914. Paulopriit Voolaine collected some words from rememberers in the 1950s and 1960s after the death of the last competent speakers in the 1930s; Adolph Johann Brandt collected some folk songs in 1849 (cf. Ernits 2012, 2018, Neus 1850 ) before the Kraasna community had been defined and introduced to the scholarly community (Kallas 1901, 1903).

As a result, the description of the Kraasna variety is still less accurate (Pajusalu et al. 2020: 200) or based upon different sources. The manuscripts from Kallas and Ojansuu's fieldwork are kept in various archives in Tartu, Tallinn, and Helsinki. They show differences depending on their source, as well as differences between these sources and published versions which were introduced during copying and transcription. The first step of the project was the collection, digitisation, and comparison of artefacts (cf. Weber 2016, 2019, forthcoming), which will be briefly summarised in the following section. During the recovery of the original sources, phonograph recordings resurfaced which had been unknown to linguists working on Kraasna (cf. Mets et al. 2014: 7) and, subsequently, not used for the description of the variety thus far. The main body of this paper aims to supply a description of these highly valuable sources with an emphasis on linking them to existing linguistic descriptions. This is not a full phonetic analysis or comprehensive morphological reconstruction but fills gaps in the description and provides observations from a different dataset to deliver further proof or falsify claims in the literature. Hopefully, this will inspire more specialist research on Kraasna, drawing from all available sources.

\section{The data}

This section gives an overview of the sources which make up the dataset on which this analysis is based. We can consider this dataset to be a corpus even though it is not published and not prepared for use in corpus linguistic analysis. For this reason, the initial discussion of the provenance, contents, and representation of the data is essential for this corpus-based study (cf. Woodbury 2011). It must be stressed that this corpus is not balanced or otherwise strategically compiled - 
it contains my transcriptions of these phonograph recordings (in the Uralic Phonetic Alphabet) and, therefore, not the entire bulk of Kraasna material. This restricts the amount of data to the intelligible parts of the recordings which means that certain words or phrases may be excluded or missing in comparison to the manuscripts due to later damage to the wax cylinders or unclear words. The exclusion of data from manuscripts and publication is justified under the premise that the transcriptions in textual sources exhibit several differences compared to the recordings (see also Weber 2016 and Weber, forthcoming). This issue is addressed at the end of this section after a description of the phonograph recordings.

\subsection{Ojansuu's recordings}

Finnish linguist Heikki Ojansuu recorded the central and most comprehensive collection of Kraasna language material between 19111914. Unfortunately, his journal and travel logs are not preserved, which limits the amount of retrievable metadata. Therefore, some information on his expeditions needs to be inferred from his field notes: Ojansuu visited Kraasna for the first time in 1911/12 on a trip to southern Estonia where he recorded about 2,000 pages of dialect language in 27 dialects (Estonica). It is unclear whether the manuscripts were created in the field or copied from earlier scratch notes; they contain almost exclusively linguistic data with occasional translations into Finnish or grammatical annotation. Metadata are only given in the headline, indicating the place of recording and, occasionally, personal names, likely of consultants (see Weber 2021). The research objective was likely related to Ojansuu's interest in phonetics, which can be seen in a very detailed use of Finno-Ugric transcription, and the subsequent publication of an article on South Estonian phonology based on these data (Ojansuu 1912).

In July 1914, Ojansuu visited Kraasna again, this time with his wife. The collected material included longer coherent narratives - different from the short phrases, single words, and song texts collected in 1911/12 - about the lives of the consultants. Ojansuu took a phonograph with him to make what became the only surviving audio recordings of coherent Kraasna, including some monologues and structured elicitation (significant phrases or words were each repeated three times). Eight wax cylinders with roughly twenty minutes of recordings survived the journey (see Appendix 1); as Mrs Ojansuu reports in 1938 (ES MT 224), 
some additional cylinders were destroyed at the request of a consultant. The surviving recordings were initially given to the Kalevala Society but are now kept in the archives of the Finnish Literature Society. They were thought to be lost by 1938 and subsequently forgotten but resurfaced during my archival work. Three of the cylinders bear Ojansuu's name, the others are filed under the name of Armas Otto Väisänen (who never visited the Kraasna community) but are labelled as Kraasna data. With the exception of one cylinder, these are clearly recordings of the transcribed data of the Estonica collection and can be linked to pages in the manuscript. As the quality of the recordings, which were copied in 1963 (and again in the 1980s), does not allow for a new transcription from scratch, I have resorted to using Ojansuu's notes as a basis for an edited transcription (see following section). However, it appears that the notes and the recordings stem from the same communicative event, either as notes taken simultaneously or later from listening to the recordings.

Some of the recordings bear Väisänen's name, therefore, I assume that he received the recordings from Ojansuu, as two recordings contain song and musical performances (no. 299 and 301; note that these numbers refer to the archive numbers of the phonograph recording rather than the numbers of the tape copies, see Appendix 1 for further information). These two recordings, along with a recording (no. 300), exhibit more wear and, as a result, more distortions and less clear sound. This may be due to repeated playing by the researchers. If they were given to Väisänen, it would appear plausible that he listened to the musical performances more often than the narratives, given his interest in ethnomusicology. Recording 299 also contains men and women talking, which may be the researcher himself - possibly in a test recording or instructions to the consultants, as the languages spoken are Finnish (a song contains the word suomalainen) or Standard Estonian. The digitisation of recording 300 is distorted at the beginning and contains shorter sentences and portions of elicitation. Furthermore, a female can be heard counting before providing example sentences and target words in particular phonological environments. Recording 301 contains three narratives following a song; one narrative is about harvesting cereal crops and another on processing dairy. The remaining recordings bear Väisänen's name. Recording 81 contains structured elicitation of words and phrases; recording 82 contains a narrative on wedding traditions 
and a partial one on baptisms as well as phrases not recorded in the transcripts, while recording 83 includes a full narrative on burial customs and a partial one on processing crops. Recording 84 contains the full narrative on weekend routines, a part of a story about a theft, and some sentences about Easter, with recording 86 consisting of elicitation exclusively. Most of the narratives were transcribed and can be linked to parts of the manuscripts (see Appendix 1).

These transcriptions from the 1914 trip were kept in an archive at the University of Tartu, where they are marked as lost; however, a copy bearing the same name is kept at the Institute of the Estonian Language in Tallinn alongside an excerpt prepared by an unknown author. The manuscripts were also copied by typewriting with the transcript kept as part one of the Estonica collection at the Finnish Literature Society. These transcripts are, at times, divergent (for more information see Weber 2016). Various scientific treatments cite Ojansuu's materials from these different sources, including a publication of Kraasna, Lutsi, and Leivu dialect texts (Mets et al. 2014). The relationship between the audio recordings and the manuscripts can be seen in Appendix 1 .

Unfortunately, there is no information on Ojansuu's consultants. His main consultants were likely known to Kallas, as his monograph contains a list of first names including several reminiscent of those in Ojansuu's manuscripts, but only Uíla [Vasiljevna] is mentioned in both authors' works. The speakers on the recordings are likely Uilía and Matrëna Rodionovna [Kuznecova] who is identified as one of the last fluent speakers until her passing aged 96 in the mid-1930s (Voolaine collected information about the last speakers in the 1950s and 1960s, which includes information obtained from Matrëna's descendants). A major issue arising from the uncertainty around the consultants' identity is the lack of biographical data. While we assume that Matrëna, as the main consultant, was originally from the Kraasna-speaking regions, Kallas notes that landlords resettled single men and women of a marriageable age from Seto-speaking regions to the Kraasna region (cf. Kallas 1903). Furthermore, we learn from Voolaine's manuscripts that the Kraasna community was visiting Seto-speaking regions, likely for religious reasons. Familial ties and frequent exchanges with other South Estonian communities might have influenced the language use of the last speakers - an important factor to consider when evaluating the reliability of Ojansuu's sources. 


\subsection{Reliability of sources}

Apart from the aforementioned issues with the speaker biographies, we must consider a range of factors pertaining to the artefacts themselves when working with Kraasna data. The most prevalent issue throughout all Kraasna textual artefacts is the intertextual links among them. While it is possible to reconstruct relationships between manuscripts or transcriptions and the recordings, we do not know about their connections precisely. The recordings may have been made at the same time as the transcripts, which may have been further edited and revised using the recorded versions; it might also be the case that the transcriptions were based solely on the recordings after the sessions. They are clearly related to the recorded speech events and were revised (insertions, deletions, commentary) as if the transcriber listened to a recording repeatedly (Note: due to the nature of the phonograph cylinders, the quality of the recording deteriorates every time it is played allowing for fewer repetitions). However, though unlikely given the number of similarities, it cannot be ruled out that the recordings were made on a different occasion before or after the transcribed speech event (e.g., recording a version after practising, recording the transcribed version, transcribing a dictated version with the stimulus of the recording).

As the sound quality of the digitised recordings did not allow for entirely new transcriptions, I used the existing manuscripts as a basis for a revised transcription. In this instance, I only altered the transcription if I could ascertain a clear difference between the recorded and transcribed versions. This does not mean that the transcriptions contained in the manuscripts are obsolete, as instances of omission may be a result of jumps in the recording or cracks in the phonograph cylinder. Consequently, the linguistic analysis in the following sections is exclusively based on the materials contained in the recordings as transcribed by me, using the existing transcriptions for guidance. Differing conclusions about the Kraasna subdialect are possible for any of the abovementioned reasons, as different speakers, different stages of language shift, different speech events, or different datasets may result in divergent interpretations of the language material (cf. Weber \& Klee 2020).

I would like to conclude this section with some comments about the transcription process. The approach chosen for creating a new transcription was born out of necessity. While it is, nowadays, possible to scan and refurbish mechanically stored recordings (Fadeyev et al. 
2005, Cornell et al. 2007), these technologies are not widely available. I hope that, in the future, it will be possible to digitise and restore the Kraasna recordings in a form that allows for phonetic analysis and supports reliable accounts of the Kraasna materials. Until then, the solution lies in the construction of the transcription. Due to their interpretative nature, transcriptions are representations of the author's understanding filtered through professional craftsmanship, personal preferences, and biases. They contain as much information on the transcriber's world view as on their transcribing skills - and basing the new transcriptions on Ojansuu's manuscripts ensures that the transcription is constructed on three researchers' opinions (in addition to Ojansuu's and my own interpretation, Jüvä Sullõv checked the transcriptions; I bear full responsibility for any errors), so biases and preferences may be reduced. Therefore, I recommend working with all original sources by the various authors simultaneously (Weber 2016) to avoid the "positivist trap of establishing an authoritative version of a text" (Seidel 2016: 31).

Although it could be argued that it is less interesting to know who authored a change in a set of data than to know under which assumptions and for which objectives it was changed (in addition to the fact that the author or editor acts on the level of the artefact and is not ascribed to the level of particular words or sentences), recording reasons for changes is more difficult and requires a high level of self-reflection. To give an example from the Kraasna transcriptions: In the manuscripts (Estonica I, 25), Ojansuu writes šiippi ('soap'), which I have changed to śîppi, under the assumptions that a) I believe I hear a palatalised alveolar and not a palato-alveolar sibilant in the recording, b) $\check{s}$ is an innovation under contact influence, c) both $\breve{s}$ and $s$ would be considered allophones of /s/ in Finnish, and d) it would fit my own interpretations of Kraasna phonology. Information on these reasons would have to be linked to the minimal change in one diacritic, which is difficult to present in plain text. I changed the manuscript transcriptions only for instances where I am (a) certain about the difference or (b) can justify the claim, while changes due to my (c \& d) personal preferences and interpretations may occasionally arise. The readers are advised to consult the original sources for comparison and be aware of claiming an objective truth which interpretative transcription methods do not permit. Despite these caveats in working with the recordings, the contained material is insightful for describing the Kraasna variety. 


\section{Methodology}

Presenting a linguistic analysis requires decisions to be made about the representation and interpretation of results. The challenge is to align the description with the traditions in Estonian linguistics and dialectology, on the one hand, while keeping the text accessible to as broad an audience as possible, on the other. I opted for a framework-free presentation of data as the guiding principle (Haspelmath 2010), while highlighting points for further enquiry in Estonian dialectology. As a reference, I used publications drawing from Ojansuu's manuscripts, allowing for a verification and re-evaluation of these findings. Firstly, there are short grammatical sketches in the Mets et al. 2014 collection of dialect texts, which list the same points as the handbook on Estonian dialects by Pajusalu et al. 2020. For the phonological description, a table of phonological peculiarities of South Estonian is given in the introduction to a volume on South Estonian sounds (Pajusalu et al. 2003). In addition, there are two important collections of maps for (South) Estonian dialectology, showing geographic spread, dialect boundaries and isoglosses: Andrus Saareste's dialect atlas (1955) covers all Estonian varieties, including Kraasna, while the maps prepared by Mihkel Toomse, edited and published posthumously by Karl Pajusalu (1998), cover South Estonian varieties only. Both sources contain occasional blanks on Kraasna data points, while other results can be re-examined using the audio recordings. A comparison to a modern South Estonian language form was facilitated by a grammar (Iva 2007) and a dictionary (Faster et al. 2014) of the literary standard of the related South Estonian Võro variety. I have indexed points of enquiry if they are linked to information found in the literature: Toomse's work is indexed by T followed by the page number, Saareste's work (1955) with Saa and a page number, information from the South Estonian comparative table (Pajusalu et al. 2003: 10-11) by LEH, and points from the dialectological handbook (Pajusalu et al. 2020: 200-201) with EMK.

The present description is data-based; however, the corpus exclusively contains transcriptions of the audio recordings (see Appendix 2). Consequently, the analysis covers only the language use of Ojansuu's 1914 consultants, which may differ from the language use of his consultants two years prior and the language use recorded by Kallas (1903) or earlier scholars (see Ernits 2018 for an analysis). A thorough description 
of the Kraasna subdialect would need to take these different layers of language into account as well as possible adstrata of other Seto varieties due to an increasing degree of mobility as the language began to shift under Russian influence. This comparative grammatical description based on all sources is left for future research. As the recordings are the main source for this work, three points are important to consider. First, the discussion is based on my transcriptions, i.e., my understanding of the recordings filtered through my own view on the Kraasna variety and South Estonian in general. I open the chance for discussion of these findings and interpretations, as anyone may contest or debate my transcriptions by accessing the recordings to falsify my claims. Second, larger entities like sentences or words are easier to transcribe and analyse, while subtle notions on the phonemic level may be obscured by the noise of the recording. I present what I believe can be heard in the recordings and flag parts which are less clearly interpretable. Lastly, I would like to remind the reader that this is a small-corpus survey with an unbalanced dataset. Thus, forms which we would expect from a stereotypical grammar may not have been recorded at all, or at least not contained in the twenty minutes of the recordings. I start with some general impressions on the language of the recordings before discussing phonological, morphological, and syntactic issues in detail.

\section{Introductory remarks about the recordings}

The language which can be heard in the recordings is clearly South Estonian and akin to varieties of Seto and shows a noticeable influence from Russian on its phonology (with a few loanwords in between). The speakers - all women, possibly the same consultant(s) - have a strong command of the language, as they can produce a narrative without longer breaks. Occasionally, the speakers self-correct or start a sentence over - this does, however, not impede the flow of speech.

There are two types of recordings. The first contains what seems to be structured elicitation of words and word forms which were important to Ojansuu's research. In these the consultant repeats words or phrases several times, occasionally in a particular context (to trigger changes or make the task appear more natural).

The remaining recordings contain coherent narratives, ranging from a few sentences to a full story. These are told in a lively fashion, 
noticeable in the use of voice and intonation. Some texts appear procedural in nature, resulting in a sequence of parallel sentence structures. Sadly, these sentences usually start with vaija 'necessary' or nakka 'I begin', which both require the use of a non-finite verb form (the infinitive and supine, respectively), leading to ample evidence on nonfinite forms at the cost of finite verb forms.

In some situations, it appears that the consultant is facing away from the phonograph, addressing a bystander or making a comment to themselves. The quality of the recording does not provide for an analysis of these exchanges. As a follow-up topic for research which is not covered here, I suggest an analysis of the pragmatics of the recordings, including the use of intonation and voice for reporting a dialogue in the narrative.

\section{Phonological structure}

The Kraasna phoneme inventory contains all the phonemes we expect to find in a South Estonian variety with length (in three phonological grades) and palatalisation of consonants being distinctive. The glottal stop is preserved (LEH), even if it is not prominently uttered in every context. It appears that all consonants can be palatalised except for the glottal stop and the weak affricate. While the glottal stop is never palatalised in South Estonian, the lack of palatalised weak affricates, which we can find in data from other Võro-Seto varieties, is likely due to the size of the corpus. Occasionally, this palatalisation can lead to a post-alveolar pronunciation of alveolar sibilants (LEH) which should, however, be seen as a free allophone or occasional variation rather than a regular shift, as it is attested only once in the recordings, i.e., koš̀jote 'to the proposal (pl.)'. The affricates appear both voiced and unvoiced (LEH) - malts 'Atriplex', matdza' 'Atriplex (pl.)'- with the unvoiced affricate clearly voiced and appearing to regressively velarise the preceding $l$ in the example. This so-called "Russian L" (LEH) - transcribed as $\langle\pi\rangle-$ is the velarised allophone of $l$ and is occasionally more velarised than in other instances, making it impossible to decide whether it is more similar to the corresponding Latvian or Russian phoneme (T43). However, its existence and use are confirmed (T26). The voiced $z$ (LEH) appears as an allophone of $s$ and may also be palatalised. This palatalisation can trigger the same retraction to $\check{z}$ (e.g., $v \bar{l} \check{z} \sim v \bar{z} z$ 'five') as observed for $\dot{s}$. Voiced consonants, while not generally as voiced 
as in Russian may be a result of Russian influence, and result in weak grade plosives appearing in non-devoiced form (T28). Foreign sounds are rare. There are no instances of $f$ and $x$ appears as an allophone of $h$ once in xàmbit 'teeth (PL.PART)'.

\subsection{Palatalisation}

Palatalisation is one of the topics extensively covered in Toomse's maps and is an interesting point for examination, as palatalisation type not only distinguishes South Estonian from Standard Estonian, but with Russian as a contact language, we expect Kraasna to differ from varieties of South Estonian with no linguistic contact with Russian. This likely contact phenomenon can be observed in Kraasna, with the front vowels $\ddot{a} \ddot{o} \ddot{u} i$ e triggering palatalisation regressively in the preceding consonant. This palatalisation could not be confirmed for every front vowel context, yet appears to be a common phonological process, e.g., teǵemà 'to do', tére 'hello', nü̈hḱtàmà 'to scrub', pérŕrä 'after', ṕät 'on top'. Palatalisation is most frequently observed for $i$ and $e$, rarely for $\ddot{u}$, and with inconclusive results for $\ddot{o}$, due to the relative scarcity of this phoneme. This type of palatalisation in front vowel contexts can occasionally be progressive (LEH), although instances reminiscent of progressive palatalisation can generally be explained with phonotactics, e.g., the elision of a front vowel following the palatalised consonant.

There are a number of contexts which are especially prone to triggering palatalisation in South Estonian, for example, the palatalisation of an alveolar nasal (T23) or lateral approximant (T27) in \#CV_i contexts. While the palatalisation of the nasal appears in pani $i$ 'I put (PST)', there are conflicting data on the palatalisation of $l$ in this context. It can be assumed that this type of palatalisation is regular, e.g., néli nellli 'four', but is not always clearly audible in the recordings, e.g., tulli 'I came'. There are no data points for the alveolar plosive in this context (T29), but we can find both palatalised and unpalatalised variants before $i$, e.g., rattite 'onto a cart (pl.)' but puhtist 'for the funeral (pl.)'. This palatalisation of the geminated alveolar plosive in words with a contraction (T64), e.g., a short illative, can be attested for other forms as well, e.g., tatti 'to the Leccinum'.

One of the most curious phenomena is the palatalisation of liquids, namely the alveolar nasal (T53) and the semivowel $v$ (T59) in \#CVi_V, 
$\# \mathrm{CVi}, \# \mathrm{C} \overline{\mathrm{V}}$ i contexts, which can be extended to the lateral approximant. Here, grade plays an important role. In forms of the second - or long - grade, the consonant is palatalised and the triggering vowel $i$ disappears, e.g., hāna ' 'hay (pl.)', revias 'piece of clothing', tềle 'to you (pl.)', while appearing as the full vowel $i$ in the diphthong before an unpalatalised consonant in the third - or overlong - grade, e.g., haina 'hay (PART)', teil 'at you (pl.)'.

Other contexts of enquiry for palatalisation include clusters of liquids and plosives. The palatalisation of a secondary cluster with an alveolar plosive $(t l, t r, t v)$ as a result of syncope (T61) cannot be precisely analysed with the present dataset, as the only suitable example is located right at a jump in the recording, i.e., tul jezä koš̀jotę tütri- 'the father came to propose [to a girl]'. It appears to me that the $t$ is slightly palatalised but not as much as in other contexts. Another cluster is $l k$ in the second syllable before $i$ (T80), which we find in pelksi 'I feared', while it is possible that an unpalatalised ?kolki 'I broke [flax]' occurs in one of the heavily distorted parts of the recordings, providing an inconclusive image. For the cluster $r k$ in the same context (T84), we find a palatalised form in sär $\mathrm{k}^{k} k i$ 'shirt (PART)'. The cluster $t s$ deriving from a historical $* k c$ or $* p c$ cluster appears palatalised in word-final position due to the apocope of $i(\mathrm{~T} 88 / 89)$, i.e., ${ }^{j} \ddot{u} t^{\prime}{ }^{\prime}<* \ddot{u} k c i$ 'one' and lat's $<*$ lapci 'child'. The same palatalisation can be assumed for forms with third syllable contraction (T90), which are unattested in the corpus.

Finally, a view on the position of palatalised consonants within a word. Palatalisation can occur in the onset and coda of syllables, thus palatalised consonants appear word-initially, -medially, and -finally. In the latter case, they may carry morphologically distinctive information, e.g., the past tense marking on verbs. Furthermore, word-final palatalisation can appear on a final alveolar nasal in nominative singular nouns after third syllable apocope (T98), as evidenced by the word hopeń 'horse'. Additionally, the apocope of $i$ may lead to the palatalisation of word-final consonants, such as the velar plosive (T70), e.g., kęik' 'all', pink' 'bench'.

\subsection{Assimilatory phenomena}

We can observe assimilatory phenomena connected to harmony in the Kraasna data. Although the existence of vowel harmony can be 
ascertained to a certain degree, there is no clear consonant harmony. While South Estonian is not known for having consonant harmony, this type of assimilatory process can be a secondary development of vowel harmony, namely when vowels lead to a consistent change in the surrounding consonants, e.g., palatalisation (as can be seen in Erzya Mordvin). The lack of consonant harmony proves that the palatalisation in a front vocalic context is not consistently applied. Despite this, we can observe an occasional syllable harmony (LEH), i.e., the fronting of vowels after a palatal consonant, as in praśśattàmmáa 'to bid farewell'. In praśśattämmáa the suffixal vowels are slightly fronted following the palatalised geminate sibilant, despite the stem being back vocalic. This example shows that the vowel harmony itself is not as steadfast as one might expect, especially when Russian loanwords are not fully adapted to vowel harmony (e.g., pra·védattamma 'to visit'). Generally, a u o e i appear in the same context (dubbed "back vowels" here), while $\ddot{a} \ddot{o} \ddot{u} e$ (i) form the opposite group ("front vowels"). There are instances where $e$ and $i$ are retracted, usually noted as $e$ and $i$ - they may then act as back vowels or just an allophone of $e$ and $i$. Especially $i$ may appear in all contexts, $o$ in certain words in final position, e.g., nägo 'face'; both are frequently encountered phenomena in South Estonian varieties. There are different types of harmonic pairs which are especially interesting to Estonian dialectology (LEH), namely the harmonic pairs $e$-e $u-\ddot{u}$ and $o-\ddot{o}$. In Kraasna, we find a clear $e-e$ harmony, the expected $u-\ddot{u}$ harmony cannot be found in the data (likely due to the limited nature of the data), while the $o-\ddot{o}$ is very unlikely. A final observation on harmony: It was surprising to hear words with palatalised consonants and front vowels end in the velarised $л \sim t$ which can be observed several times in words like $p \dot{a} \ddot{t}$ ' on top' or s' $\bar{a} t$ 'there'. In both words, the final $l$ is clearly velarised, which is another argument against consonant harmony.

\subsection{Stress}

Primary stress occurs regularly on the first syllable with odd-numbered syllables as potential candidates for secondary stress, which is common in the Finnic languages. There are only a few exceptions in the recordings: In the numerals $11-17$, the 'teen' element -te $i$-st- receives primary stress instead of the expected word-initial primary stress and secondary stressed 'teen', e.g., katśtei istkümmiend 'twelve'. This may be 
Russian influence, where the 'teen' element is stressed for all numerals in the range of 12-19. Other examples of unexpected primary stress in non-initial syllables can be found in mī jelä̈gi 'we live', hummęń om pühầääivv 'tomorrow is Sunday', and hittä edaguh magàmmà' 'I go to sleep in the evening'. Other instances are due to Russian influence, e.g., in the loanwords pravadi.t' 'to escort (in a procession)' (<nроводить 'to guide') and kata·tka 'barrow'. Importantly, clitics may be stressed (LEH), for example the negation particle in $m a_{-}^{t} t i u ̈ j a ̈ e i \cdot$. 'I do not know'.

As seen in the example above, $m \bar{\imath}$ jel $\bar{a} \cdot g i$ 'we live', there appears to be a conflation of stress and length, where the stressed syllable is lengthened. This seems to occur occasionally even in monosyllabic words, e.g., $n \bar{a}_{G} t\left(\sim n \bar{a}_{G i} i t\right)$ 'nail'. In word forms of the third (overlong) grade, which includes all monosyllabic words, this mixture of stress and secondary lengthening can exhibit an additional diphthongisation. These diphthongised forms had not fully developed into a VV vowel sequence (as in Finnish) and were in the opposite direction to the diphthongisation in Leivu (LEH), i.e., the Kraasna diphthongised forms are opening rather than closing. It may be that the initial position of the vowel is further closed and with the contour of length and stress, the position of the jaw is lowering naturally, yet, we observe this in several contexts, e.g., $k^{u}$ òrv 'basket', $k^{u}$ orgeh 'high (INE)', $r^{u}$ ottu 'swiftly', "ol 'was (3SG)', "Ostà' 'to buy', "olnu' 'been (PTCP.PST)', "'om 'is (3SG)', $k^{u}$ otn ' 'passed away (PTCP.PST)', $k^{i} \bar{e}$ dettäs 'is cooked (IPS)', $m^{i} e l$ 'at us'.

\subsection{Syllable structure}

Some interesting observations can be made about syllable structure and word form creation. In non-initial syllables, researchers have highlighted the frequent vowel elision (EMK), which is visible but not as strong as implied, e.g., kolḱtsęmma 'to break (flax)', koŕv́ḱkane 'basket (DIM)', tälttäămmä 'to pay [as a wedding present]', sermst 'ring (PART)', pābtsęmma 'to practise midwifery', kuotn' 'passed away (PTCP. PST)', rav́tsęmmà 'to feed, entertain'. Palatalisation often occurs in the contexts of an apocope of $i$, which can also be found in other South Estonian varieties. The elided vowel may be still audible in an extremely reduced form, as the speakers in the recordings break complex clusters with a pause or schwa, which is difficult to hear in the recordings but 
noticeable. This could be transcribed as a syllable break kolḱk tsęmma or a schwa vowel $\mathrm{rah}^{2}$ vast 'people (PART)'. Retracted $i$, as well as $o$, may also occur in non-initial syllables (LEH, see above). Occasionally, we can find diphthongs in non-initial syllables (LEH), e.g., tivvakkaizde 'into small bowls'.

The initial syllable is mostly interesting due to the widely-reported iotation of the front vowels $i$ and $e$ (EMK), i.e., $e i \rightarrow j e j i$ / \#_. There are forms in the manuscripts, which are not iotated but turned out to be iotated in the recordings, e.g., jikmà 'to cry', and there are at least twice as many iotated as un-iotated forms in the recordings. Not only can the data confirm this trend, but it appears that some words show a similar change $\ddot{u} \rightarrow j \ddot{u}$ /\#_. It is not quite as widespread, e.g., jütte 'together', jüldäs 'is said (IPS)', juitśs 'one', but may be a first sign of the change which can be heard in recordings fifty years later. Interestingly, this iotation cannot be observed for $\ddot{a}$. We also find consonant clusters word-initially (LEH), for which only two examples can be found in the corpus, i.e., praśśattämma 'to bid farewell', štobi 'so that', with the latter being a loan from Russian $(<ч т о б ы)$. Furthermore, the raised unrounded back vowel $i$ can be found in first syllables (LEH), e.g., kinetda? 'to speak'.

This raising of mid-high vowels occurs in two contexts. As in the previous example, before nasals, $s$, and $h$ (EMK), e.g., sics 'then', tinà 'flax', mihele 'to a man', lindas 'it flies' as well as the copula verb (LEH), i.e., um, and the reflexive pronoun (LEH), i.e., hinnèga 'with oneself'. Furthermore, the manuscripts show instances of raising overlong mid-high vowels (LEH), for which there is no instance recorded in the phonograph recordings.

The extent to which $h$ was preserved in different positions is an important element of Estonian dialectology. In the Kraasna recordings, we find it word-initially (LEH), e.g., hing 'soul', after long vowels (T49) or vowel clusters (LEH), e.g., rîh 'barn', even in a geminated form (LEH), i.e., 'rîhhe 'into the barn'. Word-finally (LEH), it occurs as part of noun stems, e.g., hamęh 'shirt', as well as in its use as the inessive suffix, e.g., perźeh 'in the bottom'.

In word-final position, $v$ is preserved as a fricative (LEH), e.g., $k^{u}$ orv 'basket', although it is not possible to establish clearly whether it is voiced after a long-vocalic syllable (T52), as there is only one occurrence, i.e., pühà̀́äìv ‘Sunday', which may be devoiced. This semivowel 
$v$ is preserved before a rounded vowel in word-final position (T60). The only potential word fitting this context is in a very noisy part of the recording but may be kaivu/kaivo 'into the well'.

A set of other points of enquiry relates to the historical development of consonant clusters. In the word takăh 'behind' (T36), we find that the velar plosive is geminated. Furthermore, the cluster $h t$ is preserved in the partitive singular of nouns exhibiting stem allomorphy ending in $h$ (T119), i.e., hameht 'shirt (PART)'. The cluster * $\eta k$ before an unstressed third syllable vowel (T121) is only attested once, as a simple voiced plosive in the form kuniga 'of the king'. The presumed metathesis of $h$ in words like vahnemba (EMK) cannot be clearly evaluated. However, it appears that there is a word vanhu 'old (PART.PL)' in one of the distorted sections of the recordings, which may speak against this metathesis.

Finally, some observations on word-final consonants. It may be the case that there is compensatory lengthening of sibilants in word-final position (T48). Yet, due to the high-pitched noise on the recordings, it is hardly possible to ascertain the length of sibilants. The only potential form is in an unsuitable context, barely audible at the very beginning of the recording, i.e., tere māmis 'hello, countryman', where I believe I hear a slightly lengthened sibilant. One reviewer pointed out that lengthened sibilants would be expected in word-final position for many words in the texts based on their equivalents in other South Estonian varieties; however, as the frequency of the sibilants merges with the noise of the phonograph and the tape recorder, the length cannot be ascertained. I agree with the reviewer that there likely is lengthening of word-final sibilants, but this would need to be measured in higher quality recordings, as it is indiscernible from listening to the recordings. Ultimately, I would like to highlight that the glottal stop does, occasionally, assimilate to the following consonant, as is also the case in other varieties of South Estonian with a glottal stop, e.g., umma perst, $m a \hat{a g} a^{k}$ $k i n n^{\prime}$ ' [covered] up with earth', añna $i^{h}{ }_{-} h \ddot{a} d \dot{a}$ ' it is not an issue'.

\section{Morphology}

The following section presents an overview of the morphology of the Kraasna data. As the dataset is small and the texts are from particular genres, an in-depth analysis of the morphology of particular noun or verb classes cannot reliably be presented here. This also affects 
the paradigms and comparative tables requested by the reviewers a larger corpus study including the remaining manuscript materials may generate further insights, as certain categories occur in parts which were not recorded on the wax cylinders. In addition to the limitations created by the small size of the dataset, there are instances in which the Kraasna data are not internally consistent, likely as a result of interspeaker variation (see section 6.3.1 for examples). Despite this variation, the Kraasna data are still coherent as regards South Estonian or Finnic morphology, e.g., stem allomorphy depending on (historical) syllable structure leading to stem or grade alternations.

\subsection{Nominal morphology}

The central concepts in nominal morphology are number and case. Overall, singular forms were much more prevalent in the corpus than plural forms. The singular is regularly unmarked; the nominative plural is marked with the glottal stop, which can be heard clearly even after syncope or vowel elision, e.g., jut' 'stories', tun'n'? 'hours'. In the genitive plural, we find changes in the final vowel triggered by the general plural suffix $-i$, e.g., rindu 'into the chest (pl.)', rîhhe 'into the barn'. This plural suffix may also cause diphthongs in non-initial syllables, e.g., tivvakkaizde 'into small bowls'. The partitive plural exhibits a strengthening or lengthening (T37), which is also common in other South Esto-

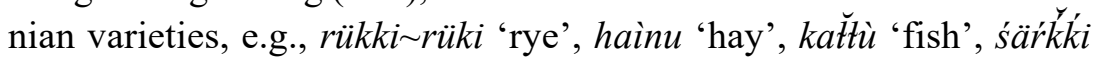
'shirts', uguritsi 'cucumbers', kapstit 'cabbages', sibulit 'onions', hàmbit 'teeth', puid 'trees'. In these examples, a vowel-marked partitive is more prominent with only the last four forms containing traces of the * $t A$ partitive marker. The genitive and partitive plural supply the stem for the semantic cases, e.g., illative hakkijatgu 'into sheaves', allative rattitite 'onto a cart (pl.)', comitative latsiga? 'with children', käsśíiga käziga 'with hands, by hand'. The latter example can also confirm the genitive plural (stem) of $k a ̈ s i$-type nouns without a change to the historical $* t$ in the stem (T68). Apart from these forms, there are no plural forms in semantic cases.

The nominative singular and genitive singular are unmarked, though grade alternation, i.e., stem allomorphy due to historical phonotactics, can distinguish these forms for some noun classes. For the partitive singular, there are no unexpected case markers, as we find vowel-marked 
forms, e.g., poiga 'son', and forms exhibiting the alveolar plosive of the historical *tA marker, e.g., jumatat 'god', rahvast 'people', 'viert 'blood', tütärd 'daughter', hameht 'shirt', hobest 'horse'. More interesting is the gemination we observe in partitive forms (EMK), namely, between the first and second syllable before a contracted syllable (T35), e.g., jï̌mmà 'mother', ješs ä 'father', timmmä 'him/her'.

We find eight semantic cases in the corpus, with six of these belonging to the local cases. The abessive was not recorded in the dataset, but, while rare, is attested consistently with - $l d A^{2}$ in the manuscripts. The terminative is only attested once in the manuscripts (Estonica V, 1945) as sēnäni' 'until now'. In spoken language use, it was likely replaced with postpositions indicating movement (Saa44), e.g., mån ' 'at', $m a n u^{\text {? }}$ 'to', virde 'to the edge'. The most frequently found semantic cases are the illative and allative directional cases and the comitative.

The illative has three types of markers: the $-h E$ marker, the $-T E$ marker, and the so-called short illative which is marked by lengthening alone. The $-h E$ marker is used exclusively for trisyllabic noun stems (T129, Saa48) in the dataset (note that vowel elision makes them appear as bisyllabic stems), i.e., kotksęhę 'into a barn', läńkkohę 'into a milk churn', kerkkohe '(in)to church', huńkkohe 'into a heap'. The illative of nouns with a monosyllabic stem (T56) cannot be analysed unambiguously. There is one occasion of a highly idiosyncratic form $t$ össe, which is translated into Standard Estonian as tööle 'to work' in the 2014 dialect collection, while we would expect tü̈̈hü in Standard Võro. It is likely an illative but may not be a form of the word for 'work'. Other monosyllabic nouns with a word-final consonant exhibit forms with a $t$ element in the illative suffix, e.g., riihte 'into a barn' - found in a barely understandable part of the recordings - and vird́de 'to the edge'. The most frequent form of the illative is the short illative, which is distinguished for monosyllabic nouns with a long vowel or diphthong, e.g., sûta 'into salt', haùda 'into the grave', with a word-final geminated consonant or consonant cluster, e.g., kirstu 'into a coffin', paiǩka 'to a place', śälgä 'onto the back (INE)', sànna 'into the sauna', mètsa 'into the forest', with VCi\#, e.g., kuhjjă 'into a stack', kàrja 'to the livestock', màrja 'to the berry', àhju 'into the oven', or VCV\# in nominative singular, e.g., patta 'into a pot', käitt- 'into a hand'.

The inessive is exclusively expressed with the suffix $-h$, also for monosyllabic nouns with a long vowel or diphthong (T93), e.g., käeh 
'in hand', which is given as kääh and kääzeh by Saareste (1955: 55), or after a secondary stressed syllable (T133), e.g., in edaguh 'in the evening'. The suffix $-h$ is consistently used to mark the inessive. The elative marker -st is only attested twice, i.e., ahost 'out of the oven', jūst 'out of the river', but consistent with other South Estonian varieties.

The exterior local cases are all attested with their expected forms, though the allative does not receive secondary stress (Saa38). The allative suffix is $-l E$ and not geminated except in pronouns (e.g., multè 'to me'). We find the forms koš̀jote 'to the proposal (p1.)', tatsęle 'to the child', jimäle 'to the mother', šuiumajtè 'for dinner time', mihele 'to a man', hobezęe 'to the horse', peremehele 'to the landlord'. The adessive is marked with -l, e.g., mehèl 'at the man', jimisel 'at the sow', the ablative with the suffix -lt, e.g., teze tt 'from the other'.

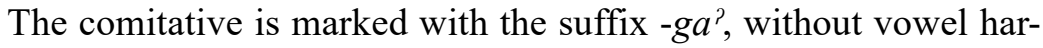
mony, and not geminated for any nouns, e.g., vig $a^{\text {? ' }}$ with water', kirvega 'with an axe'. The glottal stop may not always be audible or may assimilate to the following consonant, e.g., jimäga 'with the mother', rihàga 'with a barn', vikadiga 'with a scythe', kabtàga 'with a cable', hobęzęa 'with a horse', nàsitk'kidega 'with carrying handles', mâga 'with soil'. The translative suffix is, as indicated in the literature (EMK), morphologically the -st form. There are three instances of it recorded in the corpus, i.e., haigesst '(becoming) sick', puhtist 'for the funeral', üzest 'for the night'. The latter two forms occur as temporal adjuncts. Despite the existence of this case, it is not consistently used in all contexts where a translative form may be expected, e.g., a kujjoze? kuiva? 'but they dried [fully] dry'; rüä' sava? vàlmi' 'the rye (pl.) becomes ready [for further processing]'; $k u$ sā ei vịhma hāna' sāva kuiva? 'if it does not rain, the hay (pl.) will become dry'; ni sā haige 'and he became sick'; sā màgitkakkane 'it becomes a little tomb'. This may potentially also include sentences where there is a transition, but which may not necessarily require the use of the translative, e.g., sā pada täüz' 'the pot becomes full'; sã at hapupim 'underneath [it] turns into curdled milk'; a ṕät sā päline 'but on top [it] turns into cream'. This phenomenon is not restricted to a particular verb (e.g., $s \bar{a}$ 'becomes'), as evidenced by kujjozę kuiva?. Furthermore, although some forms may be semantically interpreted as phrasal or particle verbs, e.g., $s \bar{a}+$ tä̈̈z 'become full', $s \bar{a}$ + kuiv 'become dry', or even sā + haige 'fall ill'. kuiva? 'dry (pl.)' is an adjective, as evidenced by its number agreement; haige 'ill' is another 
example of an adjective used with both marked and unmarked translative meanings. Additionally, sā màgitkakkanę does not contain any particles or adjectives but just the unmarked noun phrase.

There are four possible explanations I would like to offer. First, there may have been free variation or idiolectal differences regarding the use of the translative. As the same narrative on burial rites contains the phrases lät haigęst 'he falls ill' and sā màgittkakkane 'it becomes a little tomb', I would ascribe this to free variation rather than interspeaker differences. Second, this variation may be a sign of language attrition or shift despite the contact language Russian also marking these translative meanings. Third, we may consider the context, i.e., the point in the discourse where the marked and unmarked versions appear. For the unmarked forms, the transition is an expected result, which can be inferred from real-world knowledge, e.g., ku sā ei viìhma hānara sāva $k u i v a$ ' 'if it does not rain, the hay will get dry', timä aettas māga / sā màgitkakkane 'they cover him with earth, it becomes a tomb'; in another instance, it can be inferred from context, i.e., kaksèt kettu är? ni sā haige '[his/her] stomach gets upset and [s/he] falls ill'. This example may be directly compared to the marked version, jeläs jeläs / ni lät haigest 'he lives, lives, and falls ill', where the change is unexpected, surprising, or a strong contrast to the previous information. This interpretation of the translative being explicitly marked in contexts where new or contrasting information is introduced, while being unmarked when a transition with a result which can be expected or inferred from real-world knowledge may require further discussion and analysis beyond the present dataset. Fourth, we may consider permanency as a feature influencing the choice of translative marking (Lehiste 1969, Stassen 1997). This approach may still not explain the inconsistency encountered in the marking of this case. As we have only one example of a marked translative on a predicate adjective in the recordings, a thorough discussion must also include occurrences in the manuscript to avoid reasoning based on counterexamples.

To close the discussion of nominal morphology, I would like to point out that adjectives can take the same case and number marking as nouns, while also being marked for degree of comparison. There is only one instance of the comparative in the corpus, which is marked with the $-b$ suffix (EMK), i.e., inää̈t 'anymore (PART)'. The manuscripts, however, contain several instances of the $-m b$ suffix, which makes it impossible 
to give a definite answer on the morphological shape of the comparative suffix. I would further like to point out that Kallas' monograph contains a form with - $b$, i.e., vahneb 'older' (Kallas 1903: 42), whereas his notepads exclusively contain the form vahnem.

\subsection{Pronouns and determiners}

We can find various types of pronouns and determiners in the text. The personal pronouns can be found in the forms of $m a^{2}, s a^{2}, t \ddot{a}$ (T24/25), with the oblique stem $m u$ and $s u$ for first and second person singular (T41). The pronouns appear in the nominative, genitive, partitive, and the exterior local cases (see Table 1).

Table 1. Pronominal forms and their allomorphs in Ojansuu's Kraasna phonograph recordings.

\begin{tabular}{|c|c|c|c|c|c|c|}
\hline & $1 \mathrm{SG}$ & $2 \mathrm{SG}$ & $3 \mathrm{SG}$ & $1 \mathrm{PL}$ & $2 \mathrm{PL}$ & $3 \mathrm{PL}$ \\
\hline NOM & $m a^{?}$ & $\begin{array}{l}s a \\
s a^{?}\end{array}$ & $\begin{array}{c}\text { timä } \\
\text { tä }\end{array}$ & $m \bar{\imath}$ & & $n \ddot{a}$ \\
\hline GEN & $\begin{array}{c}\text { mu } \\
\text { minu }\end{array}$ & $\sin u$ & timä & $m \bar{\imath}$ & & \\
\hline PART & & & $\begin{array}{l}\text { tim̌mä̈ } \\
\text { tim̌mmä }\end{array}$ & mei $[d] g i$ & & näid \\
\hline ALL & $\begin{array}{l}\text { muttè } \\
\text { muttę }\end{array}$ & suťtè & $\begin{array}{c}\text { timäle } \\
\text { tälle } \\
\text { tällè }\end{array}$ & & tèèle & näĭle \\
\hline $\mathrm{ADE}$ & $\begin{array}{l}m u t \\
m u \bar{t}\end{array}$ & sù̀ & $\begin{array}{l}\text { täl } \\
\text { täl }\end{array}$ & $\begin{array}{l}\text { meil } \\
\text { miel }\end{array}$ & teil & ńäil \\
\hline
\end{tabular}

The demonstrative pronoun $t \bar{u}$ 'that' can be found, possibly also a plural $n u$ 'those' in one of the distorted parts of the recordings as well as the demonstrative pronoun referring to a distance between the proximal and distal, $t \bar{a}$ 'that' (see Pajusalu 2015). The interrogative and reflexive pronouns appear as kiä kià 'who', partitive kedä for animate referents and mis 'what' (possibly miä in the genitive) for inanimate referents. These pronouns have been contracted with the comitative suffix into minkka 'with what' and kinkka 'with whom', e.g., ravida ote ęi minkka 'there was nothing with which to feed/cure', ote ęi minkka ahju küttä? 'there is nothing to heat the oven', ote ęi kinkka kinetda' 'there is no 
one to talk to'. This form also appears in ote ęi minkka miňnä? 'there is nothing with which to go [there is no money]', for which the referent is not clear from context - it may be about a cart or coach. Furthermore, we find the modal interrogative kuis 'how' in kuis olat (or jelät) 'how are you', the temporal interrogative kunas 'when' and pallos used in a question about amount with the meaning 'how many'. There are two local interrogatives, kos and koh 'where', in the illative and inessive, respectively. For these interrogative pronouns, a lengthened final sibilant can be assumed but is not certain from the recordings. From the relative pronoun, the indefinite pronoun kiäki 'someone' is formed in tute_ęi kiäkki 'no one comes'. A distributive form of the indefinite pronoun egàte üttèle 'to each and every one' can be found in the allative. A number of reflexive and reciprocal pronouns can be found in the texts: hin̆nèga 'with oneself' in the comitative, the complement uma 'own', e.g., lätvä [---] uma tare pōle 'they went to their own house', as well as the reciprocal pronoun jutís tęzé̀ga? 'with one another' in the comitative.

Apart from the aforementioned pallos, the other quantifiers are the

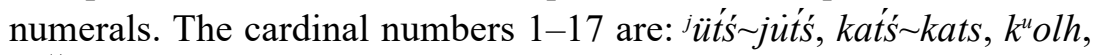

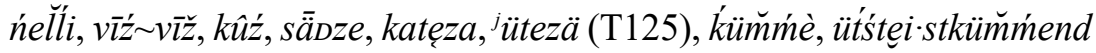

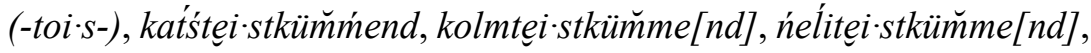

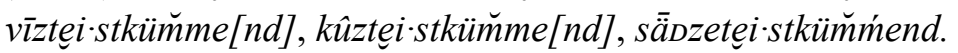

\subsection{Verbal morphology}

After discussing nominal and pronominal morphology, we now turn our attention to verbal morphology. Kraasna verbs have finite and nonfinite forms, with finite forms marked for person, number, tense, mood, and voice.

Non-finite forms include the infinitive and supine (in Estonian linguistics both are often treated as infinitives), and the participles. Historically, the infinitive had the suffix $* t A k$ which developed into a variety of allomorphs. The most clearly visible continuation of this suffix is

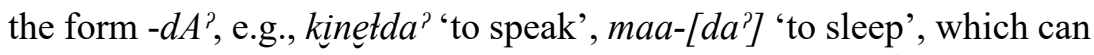
be contracted into a stem-final alveolar plosive, e.g., nitttä' 'to mow', and $a^{\text {? ' }}$ to give', alveolar nasal, e.g., min̆nä' 'to go', or geminated consonants or consonant clusters, e.g., tappà 'to kill', ra rak $o^{p}$ 'to cut trees', pesssä' 'to beat', kutsu' 'to call', messka' 'to wash'. In forms with a long vowel, the infinitive suffix assimilated into a semivowel, e.g., viı̈a' ' to 
bring', tuvva' 'to bring', forms with long $a$ or $\ddot{a}$ are not attested in the corpus. The geminated stem consonant in infinitives with a short initial syllable (T39) occurs in both second and third grade, e.g., jellä̆? 'to

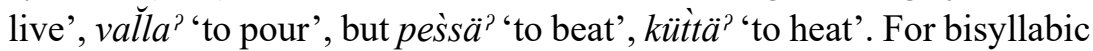
verbs with a short initial syllable and no stem allomorphy (T104), an assimilated suffix can be found, i.e., jellä $\breve{a}^{\text {? }}$. For trisyllabic verbs with the passive or causative derivational suffix *-ttA (T115), the attested forms show both a strong and a weak allomorph of the derivational suffix, i.e., tātattă ' 'to wed' but tęrmada 'to pull'. The supine, a telic infinitive, is formed with the * $m A$ suffix, which may be geminated, e.g., jistma 'to sit', pidämä 'to hold', magàmmà 'to sleep', kaütsèmmma 'to protect', katattamma 'to mangle', leźättämmä 'to lie (down)'. For verbs with a secondary-stressed syllable, such as the above-mentioned causative verbs (T128), we can see that the bilabial nasal is consistently geminated, e.g., kulattamma 'to entertain', tātattamma 'to wed', leźättämmä 'to lie (down)', praśśattämmà 'to bid farewell'.

The participles can be divided according to their formal and functional links to tense and voice categories. There are no attested forms of present tense participles, apart from a barely audible, potential form jelíä $v$ 'alive, living', which would correspond to the expected active participle form. Past tense participles are attested for active and passive voice. Examples of past tense active participles can be found as otnu $\sim^{u}$ olnu' 'been (APP)', $k^{u}$ otn' 'passed away (APP)', mânu' 'slept (APP)', kündnü 'ploughed (APP)', väzünü' 'tired (APP)' and have the suffix $n U \sim n U^{2} \sim n^{\text {? }}$. They are used for forming perfective or perfect tense statements such as om är_kuotn? 's/he passed away', and are also found in compound tense forms like the perfect passive in tä "Om "olnu pandu' 'it has been put'. This also appears with an irrealis meaning, i.e., otnu us jumatat otnu us mei[d]gi 'if there was no god, there would not be us'. The past tense passive forms have a suffix $-t$, possibly also $-T U$, in the nominative, with the vowel $u$ following in all other forms (forms showing the presumable vowel harmony are not attested in the corpus), e.g., kābęet 'dug (PPP)', pańt 'put (PPP)', tātattatu 'wed (PPP)'. The nominative plural forms pandu' 'put (PPP.PL)' and jistę du? 'placed (PPP.PL)' occur in the recordings, displaying a weakening of the passive suffix before the nominative plural marker -? 


\subsubsection{Person and number marking}

The first person singular is consistently zero-marked or unmarked in all synthetic tenses in the indicative, e.g., (ma) k' $\dot{a} u$ 'I go', (ma) ma kakà 'I sleep', (ma) ṕelgä 'I fear', (ma) jịsstę 'I sat', (ma) ṕélksi 'I feared'. The second person singular is marked with $t$ t in the present tense, e.g., ( $(\mathrm{sa})$ na ̌kkat 'you begin', (sa) leźättät 'you lie (down)', and with the glottal stop -? in the past tense, e.g., (sa) näi ' 'you saw', (sa) käve 'you went', (sa) kīj' 'you heard', with one exception where the present tense marker is used, i.e., (sa) külbset 'you sowed'. The third person has two suffixes in the present tense, as in other South Estonian varieties, a $-s$ suffix from a historical medial (Posti 1961), e.g., nakkkas 's/he begins', tätattas 's/he weds', jeläs 's/he lives', and a zero-marked or unmarked form, e.g., lät 's/he goes', jist 's/he sits', vęt 's/he takes', sā 'she/he/it becomes'. The form $s \bar{a}$ shows that monosyllabic verbs in this verb class are not marked with a $-b /-p$ element (T47) as in South Estonian varieties with a strong North Estonian influence. The same holds for bisyllabic verb stems with a short initial syllable (T100), i.e., tute 'she/he/it comes'. In the past tense, the third person singular is unmarked or zero-marked, e.g., vịh $t$ 's/he hit (PST) with a viht [in the sauna for cleaning]', kir'g 'it crowed'.

Plural verb forms are less common, especially for first and second person. There is one instance of the first person plural in present tense, which falls together with the (unmarked) first person singular, i.e., (mī) jelä jelä $\sim$ jelä $\cdot g i$ 'we live'. This phenomenon can be found in other South Estonian varieties, especially when used with a personal pronoun as in this example (see Iva 2007). In varieties where this syncretism is prevalent, the second person plural falls together with the second person singular form when a pronoun is used - there is no attested form in the corpus, but the manuscripts show a different image: There appears to be a syncretism, but with an unexpected marked form, which cannot be confirmed or falsified using the recordings, i.e., from AES $202 s a^{\text {? }}$ annàde 'you (sg.) give' - tī añnàde 'you (pl.) give'; läde 'you go'; sa istùdę? 'you (sg.) sit' - tī istùde 'you (pl.) sit'; tì àr tuñnędę? miňnū 'you (pl.) know me'; tī linah jelầde 'you (pl.) live in the city' (Estonica V). These forms seem idiosyncratic and contradict the consistent use of $-t$ in the singular in the recordings, while appearing to provide further evidence for this proposed syncretism. In the present tense, the third person plural suffixes are $-v A^{?}$ for verbs with an unmarked third person 


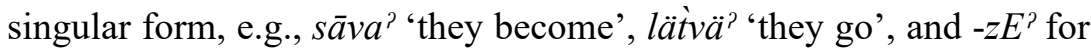
those verb classes ending in $-s$ in the respective singular forms (T127), e.g., kujjoze ? 'they dry', küzüze 'they ask'. There are not many third person plural past tense forms attested in the recordings (e.g., tuli 'they came'); in the manuscripts, we find -? for all verb types.

\subsubsection{Mood}

Grammars of modern South Estonian varieties operate with five moods: indicative, conditional, imperative, jussive, and quotative. The imperative and jussive are formally and semantically related, as the jussive is the imperative of the third person. In the present corpus we find only a few non-indicative forms. The imperative is attested for the second person singular, marked with -?, e.g., sa min' ruottu [kozima] 'you, hurry!'; mine ${ }^{k}$ kenęęe ' go and speak!'; nu min'? sa tegèmä 'now go do'; vit_timäle 'bring him/her'; pan 'put!'; tsuska sinu hand kaivu 'hang your tail into the well'. In the plural, the *-k suffix of the imperative appears as a velar plosive with an additional personal/plural marking, i.e., $-g E^{\text {? }}$ in jeläge? 'live!' or kuttetge? 'obey!'.

(1) shows an example of a prohibitive or negative imperative. The jussive is found only in the manuscripts - but not in the recordings - as the form $-g o / k o$.

$\begin{array}{lllll}\text { (1) tẹnné } & \text { ütles } & \text { àndu } & \text { ei } & \ddot{a} r^{\text {? }} \\ \text { other } & \text { say.3sG } & \text { give.NEG.IMP } & \text { NEG } & \text { away }\end{array}$

'the other says: [she] shall not be given away [as a wife]'

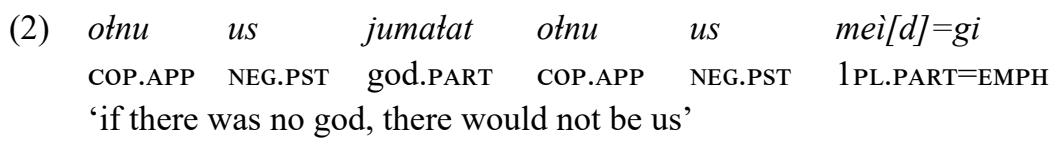

There are no clear conditional or quotative forms in the recordings. One form with an irrealis meaning uses the past tense active participle (2). This example may be poetic language, though could be indicative of a participle use for the conditional (Saa52) and potentially for the quotative as well. For the quotative, Saareste provides an example from a poetic text (Saa23) with -dav, which is also mentioned once in AES 202, 8. 


\subsubsection{Voice}

A noticeable stylistic element in the narratives is the frequent use of passive voice for the main verb. The present tense passive marker is $-T A$, which may appear in a weak form or assimilate to the stem. Only the third person or impersonal passive with the personal marker $-s$ is

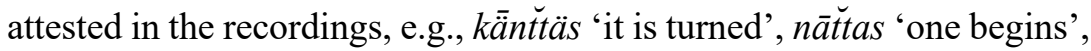
kulattas 'one is entertained', andas 'it is given', laottadas laottędas 'it is spread', tuvvas 'one brings', müvv́äs 'one sells', vījäs 'one brings'. The derivational suffix - $T A$ changes its vowel to $E$ before the passive marker, e.g., kiēdettäs 'it is cooked', nídettäs 'it is mowed', laottędas 'it is spread'. The same change applies to trisyllabic stems (Saa24), e.g., rav́tsędas 'is fed, entertained', kattęttas 'is closed shut', küdzettäs 'is baked'. Saareste's form for the present impersonal of the verb 'to speak' (Saa33) can be found as jüldäs 'it is said' with the complete elision of the alveolar plosive in the stem. There is no synthetic passive past tense in the corpus, only in the manuscripts, while anteriority is expressed with an analytic form using the participle with the copula verb, e.g., $o l$ pańt 'it had been put'; "om "olnu' pandu' 'they had been put'. A similar analytic construction with a participle can be found with a resultative meaning, e.g., haùd ku um kābęt 'when the grave was (completely) dug out'. A curious form pandaze? , likely a synthetic third person plural form, can be seen in (3).

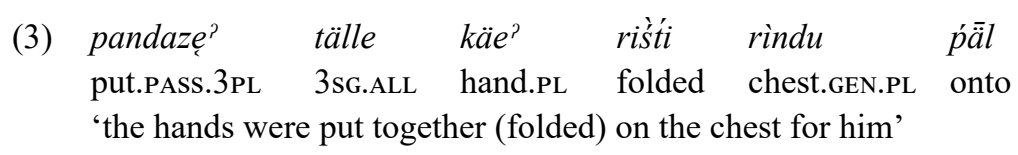

\subsubsection{Tense}

The final verbal category is tense. Present tense is not marked in the language of the recordings despite leaving traces in the shape of the personal suffixes (i.e., third-person $-s$ - for medial verbs). The past tense is marked with the vowel $-i$ which precedes the personal suffix. The first and third person singular are unmarked, e.g., tulli 'I came', tu $\grave{l}$ 'she/he/it came', while the glottal stop is used to mark the second person singular, e.g., käve? 'you (sg.) went'. This past tense marker may shorten a long stem vowel, e.g., näi? 'you (sg.) saw', assimilate to the $U$-stem vowel of reflexive verbs, e.g., sündü 's/he was born', or lead 
to change in the stem vowel, e.g., vei 'I brought'. In the (zero-marked) third person singular, it may be contracted into the stem-final consonant, leading to a palatalisation, e.g., $t u \dot{l}$ 's/he came', ki⿳亠口冋' 'it crowed', jüte 's/he said', pańd 's/he put' (Saa38), vihht' 's/he hit (PST) with a viht [in the sauna for cleaning]', kü̈' 's/he heated', na ǩkaś 's/he began'. Also found in the corpus are past tense forms containing the marker $e$ (EMK), e.g., mähke 's/he wrapped', jiște 'I sat', as well as the -si marker in peílksi 'I feared' where the plosive is preserved (T75). An interesting form using $-s E$ as the past tense marker (see Pajusalu 2005) is also found, e.g., külbset 'you sowed'.

In addition to the synthetic past tense, further past tense forms can be created with analytic constructions using participles and the finite copula verb, as in "om "olnu? pandu', ol pant 'had been put' and om

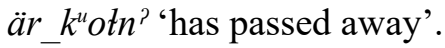

\subsection{The copula verb}

The copula verb can be found occasionally used in the recordings, but not as often as would be expected in a written text. This is especially the case with the necessitative construction, in which the copula is not used, rendering this sentence type similar to its Russian equivalent. For finite forms, mostly third-person forms are found in the recordings, more often showing a raising of the stem vowel before the bilabial nasal,

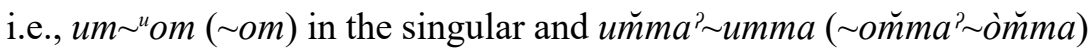
in the plural. There is one form in the first person singular, i.e., ma_ole 'I am'. In the past tense, the third person is "ol ol (T33). Furthermore, we also find the non-finite forms of the connegative, i.e., ole (ęi), and the past tense active participle, i.e., "olnu? $\sim$ otnu.

\subsection{Negation and other clitics}

Although negation is a topic of syntax, the allomorphy and morphological forms of the negative particle will be discussed in this section. The literature on verbal negation in South Estonian offers interpretations of the form as an auxiliary verb with a highly defective paradigm, inflecting only for tense, or as a pair of negation particles which exist for present and past tense. As the negation element appears as a clitic in the corpus, the interpretation of it as a particle can be favoured, although 
since the connegative form of the lexical verb is a non-finite form it would then be the predicate instead of the 'negation verb'. The negation particle may appear rather isolated from the verb and occurs in its lexical form with the stem vowel $e$, e.g., tiìjä_ei.? 'I do not know'. With increasing cliticisation, the particle assimilates to the vowel of the connegative verb, e.g., ote ęi ' is not', añna $i^{h}$ 'do(es) not give'. The same assimilation appears for the past tense particle with the unattested base form *es, e.g., otnu us 'there was not', jä äs 'did not stay'. The clitic may be stressed, i.e., tiujä_ei·?

Of other potential clitics, only the emphatic $-K i$ can be found, e.g., mei [d]gi 'we too', jel $\ddot{a} \cdot g i$ ' [we] do live', ärki 'completely away'. There are only two occurrences of the emphatic *iks in the manuscripts. The postpositions may also occasionally appear like clitics, e.g., $p$ á la 'under the head', jumata_tak̀ 'behind god', possibly also jezä_pälę 'onto the father'. This cliticisation may be due to the speed of spoken language with the (primary) stress removed from the adpositional element.

\subsection{Derivational morphology}

Apart from nominal and verbal inflection, I would like to highlight some elements of the derivational morphology present in the corpus. There are several instances of the diminutive $-k E(n E)$ and its allomorphs, e.g., sębękkęnę 'friend (DIM)', kündlekkene 'candle (DIM)', koŕv'ḱkane 'basket (DIM)', màgitkakkanę 'little tomb (DIM)'. The latter example shows that a loanword (< Russian могила 'grave') may be affixed with this diminutive derivational suffix, despite already being affixed with the diminutive of the donor language $(-k a)$. Another derivational suffix found in the corpus is the agent noun derivation $-j A$, e.g., rabah.haja 'flail; (a person?) that flails'. Adverbs are derived with the -lt marker, e.g., hummùgutt 'in the morning', tẹnagutt 'at noon', edagutt 'in the evening', jedimädzett 'first', historically other markers may have also been used, e.g., vattatè 'open'. For verbal derivation, the corpus includes examples of the frequentative *-ele-, e.g., häbendelä 'to be ashamed', factitive *-ta-, e.g., praśśattämmà 'to bid farewell', katattamma 'to mangle', as well as the historical reflexive derivation *-U-, e.g., sündü 's/he was born', korjus 'gathers', and the deadjectival progressive verbal suffix *-nE-, e.g., hap̀nes 'it curdles'. However, the derivative processes associated with these derivational suffixes were 
likely unproductive at the time of recording with these verbs having already been lexicalised.

\subsection{Loanwords}

To conclude the section on morphology, I would briefly like to discuss the treatment of Russian loanwords. These loanwords are almost exclusively nouns referring to concrete objects like tools or relate to religious language. Examples include kata.tka 'barrow', ptū [gat] 'plough', màgit tka 'grave', màgítkakkanę 'tomb (DIM)'. Other examples were not clearly understandable, e.g., the object placed in the left hand of the deceased at the burial ceremony, ?padarožij, which could be explained with no 'onto' + дорога 'way' as grave goods (it is unlikely to be a form of подорожник 'Plantago'). The examples above show that these forms are used with South Estonian inflectional and derivational morphology, e.g., the partitive case marker (ptū [gat]) and the diminutive suffix (mágitkakkane). There is one example of the complementiser štobi 'so that', and also one verb, i.e., pravadi $\cdot \dot{t}$ ' to escort (in a procession)', which fits syntactically into the South Estonian sentence as an infinitive despite not showing the borrowing language's supine marker, as in pra·védattämma 'to visit' $(<$ проведать $+-m a)$.

\section{Notes about syntax}

As dialect syntax and the syntax of spoken language could and should provide enough talking points for a separate article, I will limit this section to a few notes for further enquiry. Sentence-level phenomena are most easily checked and verified using the recordings, as the presence, absence, or order of words is clearly audible in most cases. Despite this, there are some major differences in the manuscripts, likely due to the limited number of times a phonograph recording can be played before suffering from quality loss of the physical medium. The transcriber likely focused on phonology and word-level phenomena, adding skipped words at the end or abbreviating them. An in-depth study of syntactic elements of the Kraasna subdialect is only possible with the present dataset, as the manuscripts alone are not reliable enough for definite conclusions.

The sentence structures appear interesting and different from what I might have expected beforehand, whether it is due to the fact that we are 
dealing with (spontaneous) spoken language in a monological narrative or that it is caused by the peculiarities of this South Estonian variety and its state of language contact and language shift at the time of recording. One major point of discussion, namely the motivation for marking the translative case, has already been mentioned in the previous section.

One of the reasons for the interesting word order and sentence structures is the predominant use of three sentence types: a necessitative sentence with vaija 'necessary', sentences with nakkka na k kas 'I begin; $\mathrm{s} /$ he begins', and sentences in impersonal passive voice. The necessitative construction is always clause-initial and generally appears without the copula verb. The adjective vauja triggers the use of the infinitive of the semantic main verb without exception. The necessitative construction is impersonal, as no overt subject is used. It may be analogous to the Russian нужно 'it is necessary'.

The sentence type with nakka nakkas regularly triggers the use of the supine form of the semantic verb. While nakka nakkas has the semantics of 'I begin' and 's/he begins', the use of this verb appears to be less semantically but rather functionally motivated. On the one hand, it could be interpreted as a marker of a sequence, equivalent to the conjunction 'and then' in the narration of a procedural or sequential story (4). On the other hand, it can be interpreted in a broader frame of aspectual marking as an inchoative marker for a spontaneous or intentional event in a reported dialogue (5). It may also be a syntactic calque from Russian cmamb 'stand; begin; become', which, in the source language, can be repeated in subsequent clauses.

$\begin{array}{lllllll}\text { nakkas } & \text { nāné } & \text { jịkmà } & \text { nakkas } & \text { väike } & \text { tatś jịkmà } \\ \text { begin.3sG } & \text { woman } & \text { cry.suP } & \text { begin.3sg } & \text { small child cry.suP }\end{array}$ '(and then) the wife starts crying, (and then) the small child starts crying'

(5) kedä sa nă̌kat naitma /ma nă̌kà poìga naitma who.PART $2 \mathrm{sg}$ begin.2sg wed.suP $1 \mathrm{sg}$ begin.1sg son.PART wed.suP 'who are you intending ('starting') to wed? I intend ('start') to wed (my) son'

Similar aspectual features can be observed in the beginning of the narrative on burial rites, i.e., jeläs jeläs / ni lät haigęst '(he) lives, lives, and fell ill', where the continuous aspect of the verb living is expressed by the reduplication of the verb. The phrase jeläs jeläs itself might also 
be a calque from the Russian formulaic expressions жил-поживал or жил-был 'once upon a time', but in a reduplicated form (the Russian equivalent would be an unattested *жил-жил). More visibly marked

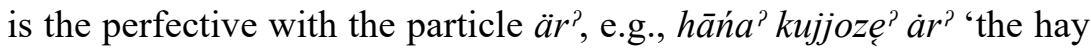
dries completely', hap̀nęs är' 'it curdles completely', męzę är? 'I wash it off', pap̀ tātattas $\ddot{a} r^{2}$ 'the priest confirms the marriage', suittas täl jo $\ddot{a} r^{?} p \hat{a} \hat{a}$, 'he is combed [until he is ready for the ceremony]', $\ddot{a} r^{?} k \hat{u} l i$ 'he

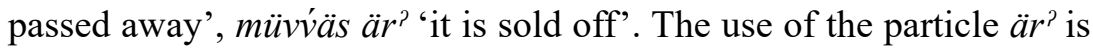
not motivated by the semantics of 'away' as in certain phrasal verb con-

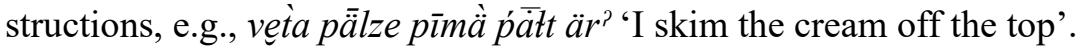

Another example of the use of $\ddot{a} r^{r}$ as part of a phrasal or particle verb is ära ă̌da' 'to give away'. As in Standard Estonian, particle verbs are fairly common in Kraasna. Other particles or adverbs which can be found in phrasal verbs include jette 'forth', ṕèr'rä 'after', kin'? 'closed; fixed', and üles 'up(wards)', e.g., panę hobęze jette 'I harness the horse', lä hainu ṕérŕä 'I go after the hay', ködä kabtàga kiñ’? 'I tie it up with wire', pandas kāzèga kin'? 'it is closed shut with a lid', kattettas timä silmä’ kin'? 'his eyes are closed shut', aettas mâgak kińn'? '(he) is covered up with earth', nānè tul̀ hummogult üles 'the woman got up in the morning', or even the illative form of the word for 'back', śâlg $\ddot{a}$, in aettas tällè hamęh śâlgä 'they put a shirt on him'. These phrasal verbs have a resultative meaning or emphasise that the process has concluded.

The third common sentence type uses the impersonal passive form of the main verb, which is attested around thirty times in the corpus. Why this form was so frequently used cannot be answered definitively, although it is, formally, a more complex form than a personally inflected finite verb, as there are, potentially, additional stem allomorphy and vowel changes; it does not, however, appear to be the form one chooses by default. The use of the impersonal passive may be linked to the genre of the narrative or may have been triggered by the framing of the question or setting of the stimulus by the researcher. He possibly asked for a general account of customs instead of a personal narrative or primed the consultants by frequently using the impersonal passive himself. Admittedly, the lines between both genres are blurred in the narrative, as it appears that the stories relate to the speakers' lives. However, the use of the impersonal passive makes it less immediate, as the verbal action becomes more abstract and less concretely tied to the particular realworld event referenced in the narrative. Having said that, the use of a 
present tense form makes the story-telling more immersive and vivid compared to the use of the past tense for referencing a remote event.

The most commonly used tenses are the present and past, with rare occasions of a more remote past, e.g., the perfect. The consultants occasionally use the tenses inconsistently for their stories, changing from past tense to present tense without a concrete, cotextual motivation, e.g., use of reported speech, which supports immersive story-telling. It appears that the consultant is not only retelling an event or reporting a custom but also commenting on it, e.g., shifting from the present to past tense in jä äs kinkka jellä̆', är? kv̂li 'no one stayed alive (remained to live with), he passed away' before returning to the procedural story with necessitatives and present tense impersonal passives. This emotional level may be heard in the intonation, for example, in the same narrative, it appears the speaker uses a lamenting, even sobbing, intonation when reporting that the deceased is buried, i.e., aettas mâga $a^{k} i n_{n}$ ' 'he is covered up with earth'.

There are some instances of more complex sentences, namely questions and sentences with a complementiser. The polar question uses the clause-initial question tag kas̀ in (6) and (7). The same text contains two instances of a complement phrase marked with et, i.e., (8) and (9).

(6) kas sa añnat ar mütę tütârd mehèl Q 2sg give.2sg away 1sG.ALL daughter.PART man.ADE 'do you give me [your] daughter for a wife'

(7) kas vet̀ pà̀ tātattă

Q take.3sg priest wed.IN 'does the priest accept ('take') [our request] to get married'

(8) kià ütles et um rikas̀ vẳjà ära an̆da? who say.3sg that COP.3sg rich necessary away give.INF 'who says that he is rich - it is necessary to consent to the marriage ('give away')'

(9) kià ütles et um hüà who say.3sg that COP.3sg good 'who (one) says that he is good'

Case and number agreement between the nominal head and adjectival attribute is observed in most cases, e.g., päalze pimä̀ 'top.GEN milk.GEN', 
hǜvä kä̈tte 'right.ILL hand.ILL', hüvvä paikkka 'good.ILL place.ILL', hāńa? sāva kuiva' 'hay.PL become.3PL dry.PL', vat̆tàtinę pink 'free.NOM.SG bench.NOM.SG', and kurra kätte 'left.ILL hand.ILL'. Occasionally, the case may be redundantly double-marked, e.g., pańd jimäle kervàle 'give.3sG. PST mother.ALL next_to.ALL' or ma jis̀tę hobęzęte śälǵğ 'I sit.1sG.PST horse.ALL back.ILL'.

Overall, we find a frequent replacement of case marking with adpositions. Especially for the (exterior) local cases, we find the analytic case marking, e.g., $m \bar{a}$ pälle 'onto (the) earth', rindu ṕäl 'onto the chest', kodo botè 'towards home'. The case governed by the postposition is mostly identical with South Estonian or Estonian forms, except in the aforementioned pańd jimäle kervalę, where we would expect the genitive jimä.

As an opposite phenomenon, the comitative is used to combine two nouns into a single noun phrase without the use of a conjunction, i.e., jezä jimàga jikva' 'father and ('with') mother are crying'. This shows the close relationship between both nouns without referring to the parents by the collective *vahnemb $a^{2}$ found in the manuscripts. This form of referring to parents can also be found in other languages around the world.

Finally, some observations about speech patterns in general. We find many examples of ellipsis, as is to be expected in spoken language use. Most often, a pronoun or the copula verb is dropped, e.g., in the necessitative. The ellipsis of pronouns (10a) seems arbitrary, as there are several examples where the pronoun is used (10b) without particular emphasis on the agent.

$\begin{array}{lll}\text { (10a) ĺä } & \text { haìn } & \text { pèrř̈̈ } \\ \text { go.1sG } & \text { hay.GEN.PL } & \text { after }\end{array}$

'I go after the hay'

$\begin{array}{llll}\text { (10b) ma láa } & \text { kodo } & \text { botè } \\ \text { 1sG go.1sG } & \text { home.geN } & \text { towards } \\ \text { 'I go home' } & & \end{array}$

For sequences, a parallel sentence structure is used, e.g., laottadas jo tav̌và rät màgit k̀a ṕälè, pandas vatsk màgitika ṕälè, pandas tịhad patà

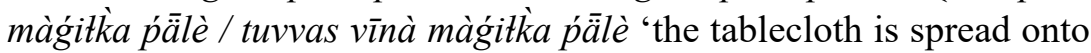
the grave, the bread is put onto the grave, the meats are put onto the 
grave, the liquor is brought onto the grave', with impersonal passive verb forms, nominal objects, and the local adverbial màgitkia ṕälè 'onto the grave'. There are only a few instances when the speakers correct themselves or start over, e.g., la- lao- / la- / laottadas 'it is spread' or $\ddot{a} r k i k \hat{u} l-\ddot{a} r^{k} k \hat{u} l i$ '(he) passed away'. The most interesting example is pandas pad́a ṕä-pandas padi ṕäla 'the pillow is put underneath the head', where the speaker notices that she used the genitive form pad́a when the nominative object padi would be regularly used after the impersonal passive verb. This shows that the speakers still had a good command of the language despite the language attrition reported by Kallas (1903). Combined with their coherent story-telling and lively intonation, it can be assumed that the consultants were able to speak the language without major difficulties, at least on the topics of their narratives.

\section{Summary}

Access to the raw materials, i.e., the sound recordings, of the Kraasna fieldwork conducted by Heikki Ojansuu allows for the scientific examination of issues of a linguistic and dialectological nature. These recordings, in theory, allow for the falsification of claims or provide examples in support of existing descriptions. While it is not possible to provide a holistic account of the Kraasna subdialect based on the phonograph recordings alone, many points and forms can be found in the data, leading to the most comprehensive linguistic description of the Kraasna subdialect to date, and the only one not to be based on the manuscripts as the primary source. My hope is that this linguistic description reinvigorates scholars' interest in further investigating the Kraasna subdialect, hopefully leading to more analyses based on Ojansuu's recordings.

The Kraasna subdialect presents itself as a South Estonian variety which is in some parts similar - in others dissimilar - to the other varieties of this dialect continuum. Kraasna exhibits a noticeable Russian influence in its phonology, e.g., the iotation of the front vowels $i, e$, and $\ddot{u}$ in word-initial position or the palatalisation of consonants in the context of front vowels, and lexicon. Despite these contact-induced phenomena, the language use on record presents a fluent and confident 
language use by the consultants. Morphologically, the language of the recordings complies with the existing descriptions, linking the variety to the easternmost South Estonian varieties of Vorro and Seto. While this similarity can be confirmed with direct observations and comparisons, the functional description of Kraasna suggests some inconsistencies, e.g., in the use of the translative case. On the syntactic level, the Kraasna recordings differ most strongly from their transcriptions in the manuscripts. Having access to a recording of the speech event makes it possible to fill gaps and enable further research into stylistic or pragmatic aspects of language use, e.g., the use of voice and intonation, levels of self-correction, and parallel sentence structures. The extent to which these characteristics are unique to Kraasna will need to be established by future research, as they may be caused more generally by spontaneous speech or the genre of spoken text.

I propose several directions for future research and enquiry into these recordings. First, it would be useful to have new digitisations made of the phonograph recordings, using modern technology (e.g., optical precision measuring) rather than relying on the 1963 tape recordings of the originals. This would allow the reduction of mechanical noise and grant access to sections of the recordings which are distorted in the tape copies, possibly providing a quality which makes the digitisation useable for phonetic analysis. Second, the present descriptive study of the recordings needs to be compared to the remaining manuscripts from Ojansuu's 1914 and 1911/12 fieldwork, ultimately being extended to the sources by Kallas gathered in 1901 and Kreutzwald/ Brandt in the mid-19th century. This may highlight differences in the speakers' language use, trends and developments, or inconsistencies in the data. The use of stylometrics or tools from forensic linguistics may help to identify the consultants based on their language use and determine whether the recordings are from one or several speakers as well as how (dis)similar their language use is compared to that of other consultants recorded in manuscripts and other data collections. Third, as the identity of the consultant(s) for the recordings is not clear, we do not know without a doubt who provided us with these clear recordings of the Kraasna Estonians' language use. A combined effort of archival research and speaker identification may provide insights into different historical stages of the Kraasna subdialect, or groups of the population which preserved Kraasna better or longer than others. It appears from 
later ethnographic accounts, that members of the Kraasna community visited Seto-speaking regions and also, as Kallas suggests, that landlords brought young men and women from Seto-speaking regions in the north as spouses for the Kraasna Estonian population in the mid-19th century. The consultants who can be heard in the recordings may be affected by either process, which could explain differences from earlier language data. Fourth, this comparative effort may be supported by the comparison of the present description and dataset with other South Estonian varieties and their descriptions. How close is the Kraasna subdialect of the recordings, or the overall language use in the manuscripts, to other South Estonian, especially Vorro and Seto subdialects? Fifth, the descriptions of syntax and sentence- or text-level phenomena should be compared and discussed under the research framework of South Estonian spontaneous speech or dialectal syntax. These comparisons should provide further insights into whether the peculiarities described hold true for other varieties or Estonian spoken language use in general, or if we are dealing with an exclusive development of the Kraasna subdialect. Finally, any gaps in the present analysis, for example pertaining to pragmatics or conversation analysis, should be closed by experts on these topics or discussed in further detail. To ensure brevity, the present overview is cursory, with many aspects of linguistic description offering work for future research into the Kraasna subdialect. Consequently, I hope that this is only the starting signal for more publications to come, and not the end of linguistic research into this fascinating linguistic enclave, its speakers, and their language use.

\section{Acknowledgements}

I am grateful to all the colleagues who encouraged and supported my work on the Kraasna subdialect, especially to Jeremy Bradley, Elena Skribnik, and Karl Pajusalu, who all supervised the initial project. I would also like to thank Sulev Iva (Jüvä Sullõv) for his comments on my transcriptions as well as the anonymous reviewers for their observant comments. I am deeply indebted to the archives which hold the original sources as well as their helpful and accommodating staff, which enabled me to access all sources and conduct my research: the Archive of the Kirjandusmuuseum in Tartu, the University of Tartu Archives of 
Estonian Dialects and Kindred Languages, the Archive of the Estonian Dialects and Finno-Ugric Languages at the Institute of the Estonian Language, the Literary archive at the Finnish Literary Society, the sound archive of the Finnish Literary Society as well as the Kalevala Society and the KOTUS archives. In addition, I would like to thank the Seto Instituut for awarding me the dissertation prize in 2019. Ultimately, I would like to acknowledge Heikki Ojansuu's work of documenting and recording Kraasna under difficult circumstances and express my respect and gratitude to his consultants for sharing their stories and enabling research even a century later.

\section{Archival sources}

AES 202 = Akadeemilise Emakeele Seltsi Ülevaated 202. Häälikuloolisi andmeid ja tekste Kraasna murdest (Archive number AES0202). Authored by Heikki Ojansuu. 1938. The Archive of Estonian Dialects and Finno-Ugric Languages at the Institute of the Estonian Language (EMSUKA). PID: 11297/3-00-0000-0000-0000-02D36L. http://emsuka.eki.ee/view/book/175/0

ES MT 224 = Emakeele Seltsi Murdetekstid. Kraasna murdetekste ja muid märkmeid (Archive number ESMT0224). Copied from Heikki Ojansuu's 1911/12 fieldwork records. The Archive of Estonian Dialects and Finno-Ugric Languages at the Institute of the Estonian Language (EMSUKA). PID: 11297/3-00-0000-0000-0000031BEL. http://emsuka.eki.ee/view/book/78/0

Estonica I-V = Heikki Ojansuu 1910-1911. Archive of Heikki Ojansuu. Literary Archive at the Finnish Literature Society. Contains a typewritten copy of Ojansuu's 1914 materials from AES 202, prepared on 05.04.1939.

EFAM Kallas M 4 = Materials of Estonian Folkloristic History. Authored by Oskar Kallas 1901. Estonian Folklore Archives at the Estonian Literary Museum.

EFAM Voolaine M 1 = Materials of Estonian Folkloristic History. Authored by Paulopriit Voolaine. Estonian Folklore Archives at the Estonian Literary Museum.

SKSÄ fonokop 32/4-8 \& SKSÄ A 530/4-7, 9 = Perinteen ja nykykulttuurin kokoelman äänitteet. Collected by Armas Otto Väisänen [Heikki Ojansuu] 1914. Digitised tape recording from 1963 and the 1980s. Sound archives of the Finnish Literature Society

SKSÄ fonokop 136/7-9 \& SKSÄ A 502/15-17 = Perinteen ja nykykulttuurin kokoelman äänitteet. Heikki Ojansuu [1914]. Digitised tape recording from 1963 and the 1980s. Sound archives of the Finnish Literature Society. 


\section{References}

Cornell, Earl W., Vitaliy Fadeyev, Carl Haber, Jian Jin, Robert Nordmeyer \& Mitchell Golden. 2007. Using optical metrology to reconstruct sound recordings. Nuclear Instruments and Methods in Physics Research Section A: Accelerators, Spectrometers, Detectors and Associated Equipment 579(2). 901-904. https://doi. org/10.1016/j.nima.2007.05.316.

EMK $=$ Pajusalu, Karl. 2020. Kraasna murrak. In Pajusalu, Karl, Tiit Hennoste, Ellen Niit, Peeter Päll \& Jüri Viikberg. Eesti murded ja kohanimed. 3. tr, 200-201. Tartu: Eesti Keele Sihtasutus.

Ernits, Enn. 2012. Fr. R. Kreutzwald lõunaeestlaste piire kompimas. In Sullõv Jüvä (ed.), Õdagumeeresoomõ piiriq (Võro instituudi toimõndusõq 26), 30-65. Võru: Võro Instituut'.

Ernits, Enn. 2018. Kraasna rahvalaulude esimestest üleskirjutustest. In Sullõv Jüvä (ed.) Valitsõmisjaotusõst keeleaoluuni (Võro instituudi toimõndusõq 33), 157-201. Võru: Võro Instituut'.

Fadeyev, Vitaliy, Carl Haber, Christian Maul, John W. McBride \& Mitchell Golden. 2005. Reconstruction of recorded sound from an Edison cylinder using three-dimensional noncontact optical surface metrology. Journal of the Audio Engineering Society 53(6). 485-508.

Faster, Mariko, Laivi Org, Urmas Kalla, Sulev Iva \& Triin Iva. 2014. Eesti-võru sõnaraamat. Võru: Võro Instituut'.

Haspelmath, Martin. 2010. Framework-free grammatical theory. In Bernd Heine \& Heiko Narrog (eds.), The Oxford handbook of grammatical analysis, 341-365. Oxford: Oxford University Press. https://doi.org/10.1093/oxfor $\mathrm{dhb} / 9780199544004.013 .0014$.

Iva, Sulev. 2007. Võru kirjakeele sõnamuutmissüsteem (Dissertationes Philologiae Estonicae Universitatis Tartuensis 20). Tartu: Tartu Ülikool. http://hdl.handle. net/10062/4860.

Iva, Sulev. 2015. Liivi, Ludzi ja Kraasna maarahva kiil. Keel ja Kirjandus 58(7). 515517.

Kallas, Oskar. 1901. Kraasna maarahwas. Postimees (Tartu) 45(152), 11. July 1901. https://dea.digar.ee/article/postimeesew/1901/07/11/2.

Kallas, Oskar. 1903. Kraasna maarahvas. Helsinki: Soome Kirjanduse Selts.

Kask, Arnold. 1956. Eesti murrete kujunemisest ja rühmitumisest. In Harri Moora (ed.), Eesti rahva etnilisest ajaloost. Artiklite kogumik, 24-40. Tallinn: Eesti Riiklik Kirjastus.

Krikmann, Arvo \& Karl Pajusalu. 2000. Kus on keskmurde keskpunkt?. In Jüri Viikberg (ed.), Inter dialectos nominaque. Pühendusteos Mari Mustale 11. novembril 2000 (Eesti Keele Instituudi toimetised 7), 131-172. Tallinn: Eesti Keele Sihtasutus.

LEH $=$ Pajusalu, Karl, Sulev Iva \& Pire Teras. 2003. Sissejuhatus. In Karl Pajusalu \& Pire Teras (eds.), Lõunaeesti häälikud II, 9-15. Tartu: University of Tartu.

Lehiste, Ilse. 1969. 'Being' and 'Having' in Estonian. Foundations of Language 5(3). 324-341. https://www.jstor.org/stable/25000387. 
Mets, Mari, Anu Haak, Triin Iva, Grethe Juhkason, Mervi Kalmus, Miina Norvik, Karl Pajusalu, Pire Teras, Tuuli Tuisk \& Lembit Vaba. 2014. Lõunaeesti keelesaarte tekstid (Eesti murded IX). Tallinn, Tartu: Eesti Keele Instituut, Tartu Ülikool.

Neus, Heinrich. 1850. Ehstnische Volkslieder. Reval [Tallinn]: Ehstländische Literärische Gesellschaft.

Ojansuu, Heikki. 1912. Ein südestnischer beitrag zur stufenwechseltheorie. Finnischugrische Forschungen 12. 147-149.

Pajusalu, Karl. 1997. Keskse perifeeria mõjust eesti keele tekkeloos. In Mati Erelt, Meeli Sedrik \& Ellen Uuspõld (eds.), Pühendusteos Huno Rätsepale (Tartu Ülikooli eesti keele õppetooli toimetised 7), 167-183. Tartu: Tartu Ülikool. http://hdl.handle. net/10062/40524.

Pajusalu, Karl. 2005. Keelesaarte se-minevik. In Mari Mets \& Sullõv Jüvä (eds.), Tartu Ülikooli Lõuna-Eesti keele- ja kultuuriuuringute keskuse aastaraamat IV, 145-150. Tartu: Tartu Ülikool.

Pajusalu, Karl. 2007. Estonian dialects. In Mati Erelt (ed.), Estonian language (Linguistica Uralica Supplementary Series 1), 231-272. Tallinn: Eesti Teaduste Akadeemia.

Pajusalu, Karl \& Liena Muižniece. 1997. Mineviku partitsiibi grammatikaliseerumisest lõunaeesti murretes. In Karl Pajusalu \& Sullõv Jüvä (eds.), Õdagumeresoomõ lõunapiiŕ (Võro Instituudi Toimõtisõq 1). 96-101. Võru: Võro Instituut.

Pajusalu, Karl \& Pire Teras (eds.). 2003. Lõunaeesti häälikud II (Publications of the Department of Estonian of the University of Tartu 27). Tartu: University of Tartu. http://hdl.handle.net/10062/55279.

Pajusalu, Karl, Tiit Hennoste, Ellen Niit, Peeter Päll \& Jüri Viikberg. 2020. Eesti murded ja kohanimed. 3. tr. Tartu: Eesti Keele Sihtasutus.

Pajusalu, Renate. 2015. Võro demonstratives: changing or disappearing?. Eesti ja soome-ugri keeleteaduse ajakiri. The Journal of Estonian and Finno-Ugric Linguistics 6(2). 167-190. https://doi.org/10.12697/jeful.2015.6.2.07.

Posti, Lauri. 1961. Itämerensuomalaisen verbitaivutuksen kysymyksiä. Virittäjä 65(4). 351-366.

Saareste, Andrus. 1955. Petit atlas des parlers estoniens. Väike eesti murdeatlas. Uppsala: Almqvist \& Wiksell.

Seidel, Frank. 2016. Documentary linguistics: A language philology of the 21 st century. In Peter K. Austin (ed.), Language Documentation and Description 13, $23-63$. London: SOAS. http://www.elpublishing.org/PID/146.

Stassen, Leon. 1997. Intransitive Predication. Oxford: Clarendon Press.

Toomse, Mihkel. 1998. Lõuna-Eesti murded 1-30. Kaardid (Publications of the department of Finnish and general linguistics of the University of Turku 56). Turku: University of Turku.

Weber, Tobias. 2016. Kraasna - The state of documentation and description of an extinct South Estonian dialect. Unpublished BA thesis at the Institute for Finno-Ugric / Uralic Studies at Ludwig-Maximilians Universität München. https://kraasna.wordpress.com.

Weber, Tobias. 2019. Can Computational Meta-Documentary Linguistics Provide for Accountability and Offer an Alternative to "Reproducibility" in Linguistics?. In 
Maria Eskevich, Gerard de Melo, Christian Fäth, John P. McCrae, Paul Buitelaar, Christian Chiarcos, Bettina Klimek \& Milan Dojchinovski (eds.), 2nd Conference on Language, Data and Knowledge (LDK 2019). Dagstuhl: Schloss Dagstuhl Leibniz-Zentrum für Informatik. https://doi.org/10.4230/oasics.ldk.2019.26.

Weber, Tobias. 2021. Consultant identity in historical language data: Anthroponyms as a tool or as an obstacle?. In Anna Choleva-Dimitrova, Maya Vlahova-Angelova \& Nadezhda Dancheva (eds.), Sliadovati dostoita. Proceedings of the International Onomastic Conference "Anthroponyms and Anthroponymic Researches in the Beginning of 21st Century”, 165-175. Sofia: Bulgarian Academy of Sciences.

Weber, Tobias. forthcoming. Philology in the folklore archive. In Lise Dobrin \& Saul Schwartz (eds.), Language Documentation and Description.

Weber, Tobias \& Mia Klee. 2020. Agency in scientific discourse. Bulletin of the Transilvania University of Braşov, Series IV: Philology and Cultural Studies 13(1). 71-86. https://doi.org/10.31926/but.pcs.2020.62.13.1.5.

Woodbury, Anthony C. 2011. Language documentation. In Peter K. Austin and Julia Sallabank (eds.), The Cambridge Handbook of Endangered Languages, 159-186. Cambridge: Cambridge University Press. https://doi.org/10.1017/ CBO9780511975981.009.

\section{Kokkuvõte. Tobias Weber: Heikki Ojansuu Kraasna murraku fono-} grammide lingvistiline analüüs. Venemaal Pihkva oblastis Krasnogorodski ümbruses elanud Kraasna maarahvas rääkis lõunaeestipärast Kraasna murrakut 20. sajandi esimese pooleni. Kõik keeleteaduslikud käsitlused Kraasna murrakust on siiani kasutanud kirjalikke allikaid, enamjaolt Heikki Ojansuu 1911.12. ning 1914. aastal kogunud käsikirju. Ojansuu tehtud fonogrammid arvati enne käesoleva uurimistöö tegemist olevat kadunud ning sellepärast pole neid varasemad uurijad kasutanud. Taasleitud helisalvestiste abil on selles artiklis kirjeldatud Kraasna murrakut esimest korda suulise kõne andmete alusel, täites lünki eelnevates analüüsides. Siinses kirjelduses järgitakse teoreetiliselt neutraalset deskriptiivset lähenemist, samas austades Eesti keeleteaduse traditsioone ja arvestades Eesti murdeuurimise varasemate tulemustega. Artikkel esitab Kraasna fonoloogia, morfoloogia ja süntaksi kohta põhiteavet, piirdudes aga korpuspõhise uurimusena fonogrammide keeleainesega. See on aluseks järgnevatele uurimisprojektidele, mis saavad käesolevat kirjeldust lähtekohaks kasutades arendada analüüsi edasi, seda laiendades ja süvendades.

Märksõnad: keelesaared, ajalooline sotsiolingvistika, Eesti dialektoloogia, keelte dokumenteerimine, fonogrammid, lõunaeesti keel, Kraasna murrak 


\section{Appendix 1: Content of the recordings}

\begin{tabular}{|c|c|c|c|}
\hline $\begin{array}{l}\text { Recording } 1963 \text { / } \\
\text { Recording 1980s / } \\
\text { Recording no./ } \\
\text { Researcher / } \\
\text { Place of recording / } \\
\text { Time of recording }\end{array}$ & $\begin{array}{l}\text { Start time } \\
\text { record- } \\
\text { ing } 1963 \\
\text { (recording } \\
\text { 1980s) }\end{array}$ & $\begin{array}{l}\text { End time } \\
\text { record- } \\
\text { ing } 1963 \\
\text { (recording } \\
\text { 1980s) }\end{array}$ & $\begin{array}{l}\text { Title of text (Eesti murded IX) / } \\
\text { description of recording / } \\
\text { page in Estonica }\end{array}$ \\
\hline \multirow{5}{*}{$\begin{array}{l}\text { A } 502 / 15 \\
\text { fonokop } 136 / 7 \\
299 \\
\text { Ojansuu } \\
\text { [Kraasna?] } \\
\text { [sine dato] }\end{array}$} & $0: 00(0: 15)$ & $0: 55(1: 10)$ & $\begin{array}{l}\text { [man talking, Standard } \\
\text { Estonian?] }\end{array}$ \\
\hline & $0: 55(1: 10)$ & $1: 11(1: 20)$ & [woman talking] \\
\hline & $1: 11(1: 20)$ & $1: 33(1: 43)$ & [man talking] \\
\hline & $1: 33(1: 43)$ & $2: 21(2: 32)$ & [man singing, Finnish?] \\
\hline & $2: 21(2: 32)$ & $3: 12(2: 54)$ & [women singing] \\
\hline \multirow{4}{*}{$\begin{array}{l}\text { A } 502 / 16 \\
\text { fonokop } 1 \\
300 \\
\text { Ojansuu } \\
\text { Kraasna } \\
\text { [s.d.] }\end{array}$} & $0: 00(0: 12)$ & $1: 27(1: 39)$ & [woman speaking, distorted] \\
\hline & $1: 27(1: 39)$ & $2: 17(2: 23)$ & Estonica I 6-7 (partial) \\
\hline & $2: 17(2: 23)$ & $2: 39(2: 45)$ & [woman counting] \\
\hline & $2: 39(2: 45)$ & $3: 10(3: 08)$ & Estonica I 6-7 (partial) \\
\hline \multirow{4}{*}{$\begin{array}{l}\text { A } 502 / 17 \\
\text { fonokop 136/9 } \\
301 \\
\text { Ojansuu } \\
\text { [Kraasna?] } \\
\text { [s.d.] }\end{array}$} & $0: 00(0: 14)$ & $0: 46(1: 01)$ & [woman singing] \\
\hline & $0: 46(1: 01)$ & $1: 50(2: 29)$ & $\begin{array}{l}\text { [story about fox and wolf, Uíla } \\
\text { Vasiljevna? See Kallas 1903] }\end{array}$ \\
\hline & $1: 50(2: 29)$ & $2: 20(3: 23)$ & Estonica I 33 \\
\hline & $2: 20(3: 23)$ & $3: 25(4: 21)$ & Estonica I 35-36 \\
\hline \multirow{4}{*}{$\begin{array}{l}\text { A } 530 / 4 \\
\text { fonokop 32/4 } \\
81 \\
\text { „Ohjelmaa“ } \\
\text { Väisänen / [Ojansuu] } \\
\text { Kraasna } \\
1914\end{array}$} & $0: 00(0: 21)$ & $2: 05(2: 25)$ & Estonica I, 28 \\
\hline & $2: 05(2: 25)$ & $2: 35(2: 54)$ & AES 202 \\
\hline & $2: 35(2: 54)$ & $3: 14(3: 33)$ & [woman speaking] \\
\hline & $3: 14(3: 33)$ & $3: 23(3: 45)$ & Estonica I, 40 \\
\hline
\end{tabular}




\begin{tabular}{|c|c|c|c|}
\hline $\begin{array}{l}\text { Recording 1963 / } \\
\text { Recording 1980s / } \\
\text { Recording no. / } \\
\text { Researcher / } \\
\text { Place of recording / } \\
\text { Time of recording }\end{array}$ & $\begin{array}{l}\text { Start time } \\
\text { record- } \\
\text { ing } 1963 \\
\text { (recording } \\
\text { 1980s) }\end{array}$ & $\begin{array}{l}\text { End time } \\
\text { record- } \\
\text { ing } 1963 \\
\text { (recording } \\
\text { 1980s) }\end{array}$ & $\begin{array}{l}\text { Title of text (Eesti murded IX) / } \\
\text { description of recording / } \\
\text { page in Estonica }\end{array}$ \\
\hline \multirow{3}{*}{$\begin{array}{l}\text { A } 530 / 5 \\
\text { fonokop 32/5 } \\
82 \\
\text { „Häät“ } \\
\text { Väisänen / [Ojansuu] } \\
\text { Kraasna } \\
1914\end{array}$} & $0: 00(0: 20)$ & $2: 55(2: 30)$ & $\begin{array}{l}\text { Pulmakombed } \\
\text { Estonica I, 19-20 }\end{array}$ \\
\hline & $2: 55(2: 30)$ & $3: 11(2: 45)$ & [woman speaking] \\
\hline & $3: 11(2: 45)$ & $3: 33(3: 10)$ & $\begin{array}{l}\text { Ristimisest (partial) } \\
\text { Estonica I, } 18\end{array}$ \\
\hline \multirow{2}{*}{$\begin{array}{l}\text { A } 530 / 6 \\
\text { fonokop 32/6 } \\
83 \\
\text { „Hautajaiset“ } \\
\text { Väisänen / [Ojansuu] } \\
\text { Kraasna } \\
1914\end{array}$} & $0: 00(0: 16)$ & $2: 52(3: 01)$ & $\begin{array}{l}\text { Matused } \\
\text { Estonica I, 21-22 }\end{array}$ \\
\hline & $2: 52(3: 01)$ & $3: 18(3: 23)$ & $\begin{array}{l}\text { Leivast (partial) } \\
\text { Estonica I, 23-24 }\end{array}$ \\
\hline \multirow{3}{*}{$\begin{array}{l}\text { A } 530 / 7 \\
\text { fonokop 32/7 } \\
84 \\
\text { „Pesemistä“ } \\
\text { Väisänen / [Ojansuu] } \\
\text { Kraasna } \\
1914\end{array}$} & $0: 00(0: 20)$ & $2: 27(2: 24)$ & $\begin{array}{l}\text { Nädalavahetusest } \\
\text { Estonica I, 25-26 }\end{array}$ \\
\hline & $2: 27(2: 24)$ & $2: 54(2: 48)$ & Estonica I, 38 \\
\hline & $2: 54(2: 48)$ & $3: 29(3: 22)$ & $\begin{array}{l}\text { Varas (partial) } \\
\text { Estonica I, } 29\end{array}$ \\
\hline $\begin{array}{l}\text { A } 530 / 9 \\
\text { fonokop 32/8 } \\
86 \\
\text { Väisänen / [Ojansuu] } \\
\text { Kraasna } \\
1914\end{array}$ & $0: 00(0: 15)$ & $3: 10(3: 28)$ & Estonica I, 1-8 (partial) \\
\hline
\end{tabular}


Appendix 2: Transcribed texts from the recordings

These transcriptions are based on Ojansuu's transcriptions contained in AES 202. In many cases, Ojansuu's detailed transcriptions can be confirmed - they were only altered if the recordings clearly do not align with his transcriptions. Due to wear on the cylinders and the mechanical noise created during copying, fine details in Ojansuu's transcription were occasionally impossible to transcribe (even for a native speaker, as Jüvä Sullõv stated in personal communication). This mostly affected the quality of sibilants and vowels, as well as length or quantity, overall. I bear responsibility for the quality of the present transcriptions and hope that new digitisations will enable narrower transcriptions or phonetic analyses in the future.

\section{$502 / 16$ (a502b 02)}

The following part is transcribed from listening impression only, the text could not be linked to any instances in the manuscripts. The sentences about harvesting could be loosely related to Estonica I, $23=\mathrm{AES}$ 202, 17 = EMIX 'Leivast'.

nu nakka ma nānę [---] / nakka ma nānę [---] / (talking in background) nakka kangast kudama / nakka kangast sâdmä / nakka kangast kudama / ma [rabataja] // nakka [---]-telemma //

[---] [riihte] 'pęima / nakka rükä [---] nakka kandma / nakka hakkijatgu 'pandma / nakka kū vidämä / ma nakka rükä atma / nu nakka rükki ṕeśsmä / nakka tarę mån’ kandma rüki / (---) / ma- / [---] //

[ma] tullì [h]ummugult üles / mezi sû kamḿ ṕấ / (---) ma (--) //

kos hobęzega lất [x3] / ma- [---] ma (--) ma tetä? / tā um munakęnę ta um $\ddot{a} r^{2}$ (---) [kervalt] [---] // [mul oll kolk- / ma kolki lin̆nu ]

nàgta? $n \bar{a}_{G} t, n a ̀ G t a ?, n \bar{a} G t\left(\sim n \bar{a} \bar{G}^{i} t\right), n a ̀ G t a^{?}$

[varbas vàrba varbas vàrba?] varвas vàrвa?

(--) maja vaija maijjā vaüjà?

haràk haraga? [x3]

tak̀ olę_ęi xàmbit mut, tak̀h olę_ęi hàmbit mut, tak̀h olęęi hàmbit mut ma- (--) vabā nānéè, tū um vaba nāné, tū um vă̌ba nāñ́ę] malts, matdza? [x3]

nęgęzę umma ṕerst pes̀s ä? nęgęze umma ṕerst pes̀s ä? nęgęz_umma ṕerst pes̀s $\ddot{a}^{?}$ 


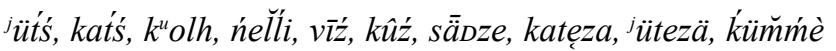

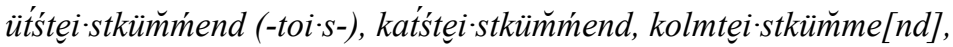

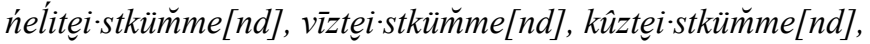
sǟDetei $i$ stkümḿnend

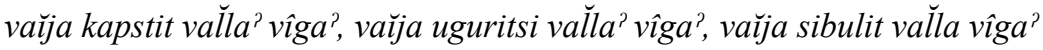

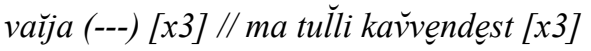
ku um väzünü? sa ei jevvva? [x3]

\section{2/17 (a502b 03)}

[singing, a song with every line starting in "liiku" or "niiku"]

[The following part is mostly unintelligible; it is a version of a story about a fox tricking a wolf but not equivalent to the version in Ojansuu's manuscripts (recorded in Estonica $\mathrm{V}$ in 1912). The text is very similar to the story told to Oskar Kallas by Uíla Vasiljevna (1903: 126) and might be from the same consultant. This part needs to be revisited when better audio quality is available, as it is impossible to link the recording to a section in the manuscripts.]

[suzi ja repän olíli] [---] [taluga hingämä] / repän [nigu] kallo [ni sa püvvä kallo] / tsuska sinu hand kaivu [ja] korjuz hanna tä̈̈z kallu / [susi] timä hanna kaivu ja kaivu är? hand külmi jẩ kinni (-) repän [küllä küläh] jütles [külämehe] (--) / külä rahvas / hüä rahvas / suzi sit kaivu / [---] veta sul (-) lats [---] / [jeläse] kęik (---) mu küllä / sa jözęt víert a ma jözę mättä //

haìnu vikadiga nídettäs / rihàga rīpttas / ümbre kǟnttäs štobi haìna kujjozę? / a kujjozę kuiva? / hāna' kujjozę àr pane rukka / lä panę hẹb-

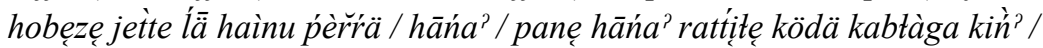
vìn (n) hāna kūp / kän(ä) Gūrmà külè pälé / nakka haìnu kolítsęmma / nakka kotksęhę haìnu kàndmà //

nüšä ma lehmä hommmigutt / nüšà̀ eddagutt / nüssä ma lehmä hummùgutt ni nüsssà [ku] tẹnagutt ni nüšsà (-) / pīmä ma? kurna paitta sā pada tä̈̈ż /

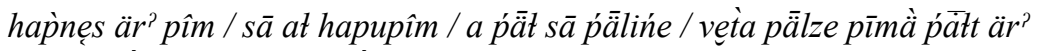
/ panę àhjo pīzlem̌́mä / a host ma veta us̀sę nakka veezíind téǵemà̀ / ni ma vęta vęi- vęiźme / męzę är? / panę ma vęiźme sûta / hapu pīmä panę àhju / [---] ahost us̀sẹ kohopimä / kohopimä läńkkohę panę kivi ata / panę śol pīmä sûta / hoŭjà šettä̀ (---) 


\section{0/4 (a530a 04)}

tére māmīs kuis olat (jelät) [x3] I

kuńiga nāne [x3] /

taha- (---) / ülegòh [s] [x3] / jumata_tak̀ mī jelä.gi jumata_taǩăh mī jelä jumata takăh mī jelä / otnu us jumatat otnu us mei [d]gi [x3] /

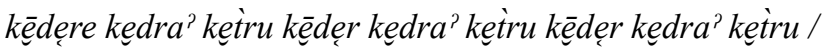

ote ęi minkka minnnär rahad otę ęi [x3] /

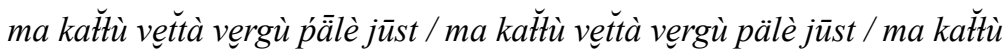
vęttà vergù pälè jüst / ńi tẹbras ńi tep̣ra? [x3] /

ma lä kodo botè [x3] /hädà

kabęhhęzęt tuli / sẹbęrkkęnę tul / hębęhhęnę tul /

jimäl uoĺ viž poiga / jimäl uol viż́ poiga / jimäl voĺl viź poiga /

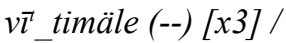

rûg nii rûsk [x3] /

vă̈a ra káko ${ }^{p}$ puid kirvega? [x3] /

mī kuòrv mī koŕ́ḱkkanę [x2] / mī kuòrv mī koŕv́-jedimädzett / jedimänne jedimädzelt / jedimäne jedimädzett //

añna_i $i^{h}$ hädà häbendelä? văja kjjulh [x3] /

muna(n) hüvä (---) /

tsirb 'lindas̀ ’korgẹh muna ’perźeh / tsirk 'lindas̀ kuorgẹh muza- muna ’perźeh / tsirk 'indas 'korgẹh muna péerźeh //

kaksèt kẹttu är ${ }^{2}$ ni sā haige [x3] /

vanhu asju [x3] [---] / ṕelgä ma peélksi ma ṕelgä ma peélksi ma ṕelgä ma pélk- (--) /

mu harak mu haragà [x3] [---]

kui kündnü nī külbset [x3] /

tinà rabah·haja [x3] /

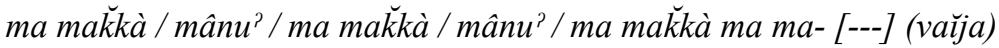
văja maa-[da] 


\section{$\underline{530 / 5(\mathrm{a} 530 \mathrm{a} 05)}$}

tul jezä koš̀jotę tütri- [---] tullí košjote suťtę // (faces away from the phonograph) / kedä sa năkkat naitma? / ma năkkà poìga naitma / kas sa

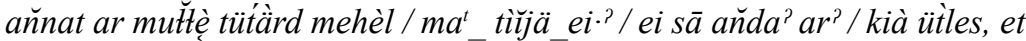
um rikas̀ vaùjà ära añda? / tẹéné ütles àndu ei är? otę ęi hüà / kià ütles et um hüă / mine kenęte / näal lätvä jut̀ jütte / năkkaś hähki teǵèmầ / vajà miňnä? papi mån? / kas̀ vèt pap̀ tātattă? // pap̉ năkkas küzù̀mä [---] kunas teil sāva? [---] sāva? hot iisṕäüu / pallos meil rahvast sā / [faces away: no vuot lä nu / lä nü sinnä] // ma lä kozitazęga? mevzjat kenęlda / inemist kümḿe sāìja lät / śät na ǩkas sata hoitma rav́tsęmma / vīnàga jūtma / ni tastas ärki / jezä jimà̀ga jịkva?, lätvä’ tātattamma, lätvä’ kerkkohe / pap̉ tātattas är? / pap̀ and sermūzè näile kätt- [---] sevrmst otę ęi / sịs năkka_i

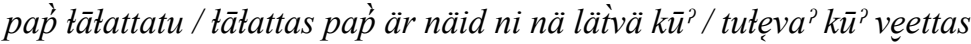

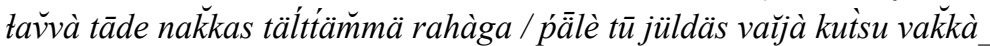

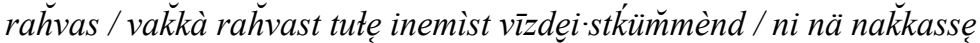
tagaźi rav́tsęmmà / ni nakkas vīnàga jūtma / nu rav́tsędas är? nāttas kuĺătă̌ma nāttas kàrgamma _ nāttas [jàrmulit]] (-) lüümä / kuĺăttas kuĺăttas ńi lätvä [---] uma tare pōlę /

jeläge? nu kui tèle jumal ànd / kuttętge? ješsä ńi kuttętge? jimmà̀ / nu vot hähä kęik / nädäli jeläs / lät imä potè kośtma /

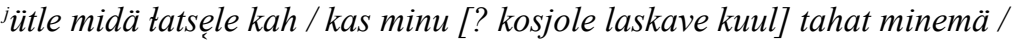
sa min? ruottu [kozima] //

inemene sündü mā pālè / ińemine sündü mā ṕälè / (--) kuts pāba / nakkas last pāb́tsęmma / pābtś latsę är? / lä̀t küt sañnà / vêt sis lätśsís_saǹna / mesśk vîga? ni vịht vihàgà? ni mäh̀ke mäh̀ku / ńi tul tarè mån? ni pańd jimäle kervàlę [---]

\section{$\underline{530 / 6(\mathrm{a} 530 \mathrm{a} 06)}$}

(-) jeläs, jeläs ni lät haigęst, (--) haìgę, leźättäs, tute_ęi kiäkki pra·védattă̌ma tim̌mä [---] mis sa leźättät, mis sù̀ um haigę. [---] leźättät, leźättät ma_olę keik tebinę [ei jovva] [---]

(---) ärki kûl- ärk kûli uoĺ ar̆mas và̀egä! _ vaija kutsu? mèskmà, mestas är? suittas täl jo är? ṕấ, aettas tällè hamęh śâlgä, aettas tällè hamęh [---] nu pingì pälè tälle säettas azęnd, taottadas tällè tav̌và rät [? pingì̀ pälè], pandas timä lézättämmmä [---] nakkas nāné jịkmà, nakkas väike tatś jịkmà

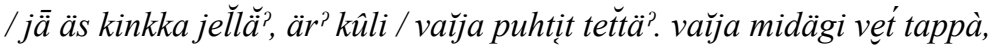
vaja puhtist hot tam̌mas̀ / tappà. / vẳja miňnä t’össe, tettä kirst, / pandas 
kìstu, pandas kāzèga kiñ?. laottędas kirstu revias, pandas pad́a ṕäpandas padi ṕäla // pandas timä kirstu leźättämmmä, kattettas timä sil̆mä? kiñ?, (-) pandazę tälle käe? riśti rìndu ṕäl, nu vot / nāttas puhtịt teǵèmä / koŕattas rahvast, rûga kiēettäs, vat̀sku küdzettäs // timä nàśitḱkidega (-) kerkkohę / (-) nakkas kerkkohę kandma / śät nakkas pap̉ tim̌mä pravadì ‘’ / täl̆è andas kurra kätte (padarožij?), hüv̀ä kätte andas kündle ̌kkene // ńi kattęttas timä sū kinńi / (-) praśśsttàmmà pandazę? kāzèga (-) kìn'? [---] (-) vījäs tim̌mä havva manu?. haùd ku um kābęt / timä tastas haùda / aettas mâgak kińn'? / [vettas] (---) / tällè pandas jàtgu ku [? ei] jumata kumarda? / timä aettas māga / sā màgitkakkanę (--) la-lao- / la- / laottadas jo tăvà̀ rät màgittka ṕälè, pandas vatsk màgitk̀ ṕälè, pandas tịhad patà màgittka ṕälè / tuvvas vīnà màgitłka ṕälè (-) /, nāttas hì̀ge ülendämmä: hing hüvvä paikka nāttas puhticst śeŕbämmä //

vot̀ ma- ma? / jelä nu lat̀siga? kuis tahat [---]

(-) rüä’s sava? vàlmi’, vaijā miňnä? pèim [ma] / (-) ei otę minkka pè̀ima,

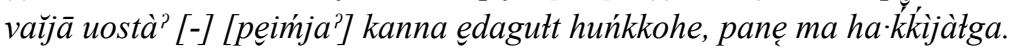
[---] rüä? är? peimi, nakka kū vidầmà, nakka kuhjă pand- [---] (-) vaija atta? rîh'he / vaija rîh panda? küttümä / hummęń nakka rīht ṕes̀-

\section{0/7 (a530a 07)}

hamęh jo um must̀. vaŭja hamęh mes̀ka?. vaŭja panda tịkku, vă̌ja kīttä? tịbęhęt, vaŭja uosta? śîppi. vaŭja vuetta? hamęh / panę ma hammę lìkku (? hammęrriikue hammęrruikue) käziga ma męze / vī vī vīrde / nakka

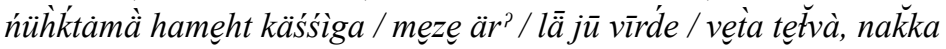
tẹtvàga ṕè̀mä (-) na ̌̌ka ju uhtma vīga? / ṕälè tū nakka pürdmä panę tęñna ṕälè kuŭjoma / kŭjos är? / vaüja tuvva? tare mån? / vèta vaĺoga ńi kata·tk̀a ńi katattamma hammę ä- (-) pülpühà küttettäs sà̀ / lä ma sàǹna / na ǩkka ma vihàga víhtma nakka ma ṕäd meskma / męze nägo viiga / huha àr ma ei ke $e^{h}$ vîga / ä ma puhta hă̌męe(') sälǵä, ä ma puh̀ta [?] kādsa siird́e / nu lää ma tare mån? ar? / sā ẹdàg / năkka eddak pidämä / hittä êdaguh magàmmà· /

hum̌męń om pühàpääv / tutè kẹha ṕäl üles / mesze sū / kumarda jumatat / nu miń? sa tegèmä, miä sựtè vaŭjà, kiä lät kàrja, kiä lät hobęst kaŭtsèmma / aga mètsa tattí a kiä lät màrja / šuumaig keik korjus tare mån? / nak̀ka

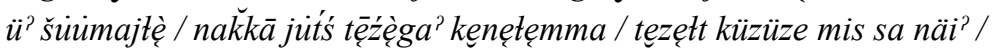

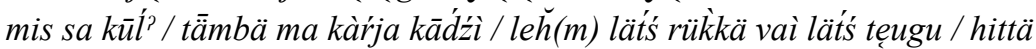
nu hingämä pälè šúmajà / lää kostma lịhavẹtte ãde botè (-) / panę hobęze jette ńi lä kositma / vêtta latse ka hiňnèga / lä kostma pāba pole mu latśs 


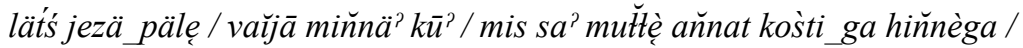
pan muttè hot veezíind / tivvakkaizdę hiñnèga //

tuĺ varas̀, tuĺ varas̀ vargilt tä uom uoĺnu? pandu? värä? kiǹ? täal uoĺ mero kevá. kasuĺ ol pańt mero ṕäle ûzest. nāné tul̀ hummogult üles, kaes: verä vătàtè. lätś ńi ütles mihele: verä văttatè. sa käve? ùšse[h]. ei ütles ma

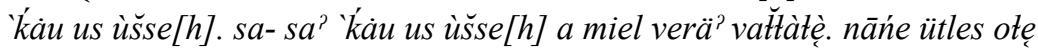
i ińäbät ptū-

\section{$\underline{530 / 9(\mathrm{a} 530 \mathrm{~b} 01)}$}

är vęttú_i seťtà $[x 3]$ /

pan hopęń jette $[x 3]$ /

ravida otę ęi minkka [x3]

[---] minkka ahjo küttä’ otę ęi minkka ahju küttä' otę ęi minkka ahju- [---] mā om jezändä rah̀vă k̈äeh [x2] mā on jezändä [---]

à̀? om är_kuotn? / mu jezä om à̀? är kuotn? /

kap[st] a o ŏma? jistędu? / kap[st] a òmma jistędu? / kap[st] a òmma jistęedu? /

ma kana pane jịstma munna ṕälè / ma kana pane jịstma munnå ṕälè / ma kana pane jistma munn- [---] kotm nädälit jịst kana [x3] /

vaüja haina nĭttää? [x3] / vaüja haina rîbu? [x3] [---] vaŭja haina rukka panda? [x2] / sā ei vịhma hāńa? sāva kuiva? / ku sā ei víh̀ma hāńa? sāva kuiva? / ku sā ei víhma sāva hāna? kuiva? / vaŭja haìna viüä? ku? / vaüja

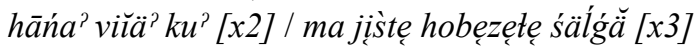

[---] pīppu tĕmbada (-) pīppu tĕmmada? / sa tahat pīppu tĕmma[da?] /

viǔjäs sinnä? lînă müvv́äs är? [x3] / sā peremehele rahà [x3] /

ote ęi kinkka kinętda? [x3] [---] egàtę üttèle hüä [x3]

[---] kikas kir’́g [x2] /

ma meištà kię [x3] /

jütś tă̌mas / kiiḱk tamba? [3x]

kae koh sa jelät [3x] [---]

[nu sant jelä?] [---]

ma timähă̌và koi śäř́ḱi [x3]

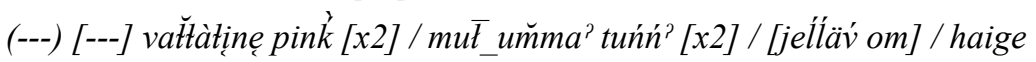
[---]

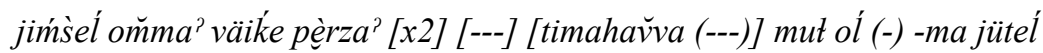
/ mut ol katś ĺehmä / ma vei är? jäi jütśs / mut ol katś ĺehmä / ma vei är? jäi jütś 